\title{
Portrait of multifaceted transporter, the multidrug resistance-associated protein 1 (MRP1/ABCC1)
}

\author{
Éva Bakos • László Homolya
}

Received: 2 January 2006 /Revised: 10 May 2006 / Accepted: 24 May 2006 / Published online: 23 December 2006

(C) Springer-Verlag 2006

\begin{abstract}
MRP1 (ABCC1) is a peculiar member of the $A B C$ transporter superfamily for several aspects. This protein has an unusually broad substrate specificity and is capable of transporting not only a wide variety of neutral hydrophobic compounds, like the MDR1/P-glycoprotein, but also facilitating the extrusion of numerous glutathione, glucuronate, and sulfate conjugates. The transport mechanism of MRP1 is also complex; a composite substratebinding site permits both cooperativity and competition between various substrates. This versatility and the ubiquitous tissue distribution make this transporter suitable for contributing to various physiological functions, including defense against xenobiotics and endogenous toxic metabolites, leukotriene-mediated inflammatory responses, as well as protection from the toxic effect of oxidative stress. In this paper, we give an overview of the considerable amount of knowledge which has accumulated since the discovery of MRP1 in 1992. We place special emphasis on the structural features essential for function, our recent understanding of the transport mechanism, and the numerous assignments of this transporter.
\end{abstract}

É. Bakos

Institute of Enzymology, Hungarian Academy of Sciences,

Karolina út 29-31,

1113 Budapest, Hungary

L. Homolya $(\triangle)$

Membrane Research Group for Membrane

Biology and Immunopathology,

Hungarian Academy of Sciences, National Medical Center,

Diószegi u. 64,

1113 Budapest, Hungary

e-mail: homolya@biomembrane.hu
Keywords $\mathrm{ABC}$ transporter Xenobiotic transport . Multispecific organic anion transporter.

Multidrug resistance . Cancer drug resistance .

Glutathione conjugates · Detoxification

\begin{tabular}{|c|c|}
\hline \multicolumn{2}{|c|}{ Abbreviations } \\
\hline $\mathrm{ABC}$ & ATP-binding cassette transporters \\
\hline MDR & multidrug resistance \\
\hline MRP1 & $\begin{array}{l}\text { multidrug resistance-associated protein } 1 \\
\text { (ABCC1), ABCC-type protein }\end{array}$ \\
\hline $\mathrm{ABCC}$ & $\begin{array}{l}\text { C subfamily of ATP-binding cassette } \\
\text { transporters }\end{array}$ \\
\hline MDR1 & $\begin{array}{l}\text { multidrug resistance protein } 1 \text { (P-glycoprotein, } \\
\text { ABCB1), ABCB-type protein }\end{array}$ \\
\hline MDR3 & $\begin{array}{l}\text { multidrug resistance protein } 3 \text { (ABCB4), } \\
\text { ABCB-type protein }\end{array}$ \\
\hline MRP2 & $\begin{array}{l}\text { multidrug resistance-associated protein } 2 \\
\text { (cMOAT, ABCC2), ABCC-type protein }\end{array}$ \\
\hline sPgp & $\begin{array}{l}\text { sister-P-glycoprotein (BSEP, ABCB11), } \\
\text { ABCB-type protein }\end{array}$ \\
\hline CFTR & $\begin{array}{l}\text { cystic fibrosis transmembrane conductance } \\
\text { regulator (ABCC7), ABCC-type protein }\end{array}$ \\
\hline SUR & $\begin{array}{l}\text { sulfonylurea receptor (ABCC8 and } \mathrm{ABCC} 9) \text {, } \\
\text { ABCC-type protein }\end{array}$ \\
\hline ABCG2 & $\begin{array}{l}\text { multidrug transporter (breast cancer resistance } \\
\text { protein, MXR/BCRP/ABCP) }\end{array}$ \\
\hline NBD & nucleotide-binding domain, $\mathrm{ABC}$ domain \\
\hline TMD & transmembrane domain \\
\hline TMH & transmembrane helix \\
\hline MOAT & multispecific organic anion transporter \\
\hline $\mathrm{LTA}_{4}-\mathrm{D}_{4}$ & leukotriene $\mathrm{A}_{4}-\mathrm{D}_{4}$ \\
\hline GSH & reduced glutathione \\
\hline GSSG & glutathione disulfide \\
\hline GS-X & glutathione conjugate \\
\hline
\end{tabular}




\begin{tabular}{|c|c|}
\hline $\mathrm{E}_{2} 17 \beta \mathrm{G}$ & estradiol-17- $\beta$-D-glucuronide \\
\hline NNAL & 4-(methylnitrosamino)-1-(3-pyridyl)-1-butanol \\
\hline ALLN & $\mathrm{N}$-acetyl-leucinyl-leucinyl-norleucinal \\
\hline VP-16 & etoposide \\
\hline AML & acute myeloblastic leukemia \\
\hline ALL & acute lymphoblastic leukemia \\
\hline CLL & chronic lymphoblastic leukemia \\
\hline SCLC & small-cell lung cancer \\
\hline NSCLC & nonsmall-cell lung cancer \\
\hline LRP/ & lung resistance-related protein, major vault \\
\hline MVP & protein \\
\hline CYP & cytochrome P450 \\
\hline AM & acetoxy methyl ester \\
\hline MK571 & $\begin{array}{l}\text { inhibitor of MRP1, MRP2, MRP4, and MRP7; } \\
\text { LTD }_{4} \text { receptor antagonist }\end{array}$ \\
\hline Nrf2 & nuclear factor-E2 $\mathrm{p} 45$-related factor \\
\hline Ycf1 & yeast cadmium factor- 1 \\
\hline Kir6.2 & inwardly rectifying $\mathrm{K}^{+}$channel \\
\hline MJ0796 & $\begin{array}{l}\text { Methanococcus jannaschii hypothetical ABC } \\
\text { transporter }\end{array}$ \\
\hline HlyB & Escherichia coli hemolysin transporter \\
\hline MalK & $\begin{array}{l}\text { ATP-hydrolyzing subunit of the Escherichia } \\
\text { coli maltose transporter }\end{array}$ \\
\hline $\operatorname{Rad} 50$ & Pyrococcus furiosus DNA repair ABC ATPase \\
\hline BtuCD & Escherichia coli vitamin $\mathrm{B}_{12}$ importer \\
\hline MsbA & Salmonella typhimurium lipid A transporter \\
\hline PKC & protein kinase $\mathrm{C}$ \\
\hline ROS & reactive oxygen species \\
\hline $1-\mathrm{GC}$ & $\gamma$-glutamylcysteine synthetase heavy subunit \\
\hline
\end{tabular}

\section{Introduction}

Multidrug resistance (MDR) is a major impediment to successful chemotherapy of cancer. The MDR phenotype is frequently associated with the overexpression of the MDR1/P-glycoprotein, which was identified as an active drug-extruding transporter with a broad substrate specificity. This distinctive feature of this drug pump explained the cross-resistance to a series of structurally and functionally unrelated anticancer agents. However, numerous unexplained cases of MDR phenotype implicated the existence of other mechanisms for MDR. Identification of the multidrug resistance protein 1 (MRP1, also denoted as $\mathrm{ABCC} 1$ ) in 1992 [24], and its initial characterization, elucidated that this protein indeed represents an alternative drug pump. The MRP1 gene maps to chromosome 16p13.1 and encodes for a protein of 1,531 amino acids. Sequence analysis identified MRP1 as a member of the ATP-binding cassette $(\mathrm{ABC})$ superfamily, to which the MDR1/P-glycoprotein also belongs. MRP1 is an integral membrane glycophosphoprotein with an apparent molecular weight of $190 \mathrm{kDa}[3,41]$ and functions as a primary active transporter utilizing the energy of ATP binding/hydrolysis $[25,181]$. The transport activity of MRP1, similar to that of other ABC transporters, is characterized by vanadate sensitivity and lack of a phosphorylated intermediate. Like MDR1/P-glycoprotein, MRP1 also possesses a broad substrate specificity and can confer resistance to a wide variety of anticancer agents in tumor cell lines [25, 45, 181].

Subsequent analysis of MRP1 revealed that, in contrast to MDR1/P-glycoprotein, MRP1 also transports organic anions such as compounds conjugated to glutathione, glucuronate, or sulfate $[60,80,102]$. Following this perception, MRP1 has been identified as one of the elusive multispecific organic anion transporters (MOATs) or glutathione-conjugate (GS-X) pumps, which were described well before the discovery of MRP1. Since the cellular release of the inflammatory cytokine $\mathrm{LTC}_{4}$ was attributed to the activity of MOATs, the MRP1 transporter has been proposed to play a role in leukotriene-mediated inflammatory responses [80]. Similarly, efflux of oxidized glutathione (GSSG) from cells during oxidative stress was reported years before the cloning of MRP1. The ability of MRP1 to transport GSSG [79] made this transporter the number one candidate for the GSSG overflow system.

Collectively, with the detailed investigation of MRP1, several previously discovered phenomena, such as non-Pglycoprotein-mediated drug resistance, transport of conjugates, and cellular release of $\mathrm{LTC}_{4}$ and GSSG, converged and became explainable by the function of a single transporter. Due to its extraordinary transport properties, MRP1 contributes to several physiological functions and pathophysiological incidents.

\section{Structure of MRP1 and the role of the amino-terminal regions}

The cDNA encoding MRP1 was first cloned from a doxorubicin-selected, multidrug resistant human lung cancer cell line (H69R) by differential cDNA screening [24]. As mentioned above, on the basis of its primary sequence, MRP1 has been classified into the superfamily of $\mathrm{ABC}$ transporters. Thus, it contains characteristic short ATP-binding motifs (Walker A and Walker B) and inbetween an additional conserved sequence ( $\mathrm{ABC}$ signature motif). In addition to sequence homology, $A B C$ proteins share a common molecular architecture: they are composed of the combinations of nucleotide-binding domains (NBDs), which harbor conserved peptide motifs, and transmembrane domains (TMDs), which generally consist of six transmembrane helices (TMHs). 
Subsequent to the cloning of MRP1, several MRPrelated proteins have been identified and classified into a subfamily. By the systematic classification of the human $\mathrm{ABC}$ transporters, the nine human MRPs, together with the cystic fibrosis transmembrane conductance regulator (CFTR) and two sulfonylurea receptors (SURs), form the ABCC subgroup. Accordingly, a systematic name, ABCC1, has been assigned to MRP1. In contrast to other $A B C$ transporters, which exhibit a high similarity between the two NBDs, members of the ABCC subfamily share the peculiarity of "NBD asymmetry", that is, the two NBDs are fairly dissimilar in these proteins. The main difference comes from a small 13-amino-acid-long sequence between the Walker $\mathrm{A}$ and the $\mathrm{ABC}$ signature motifs, which is present only in the C-terminal NBDs (NBD2) of ABCC proteins. Other $\mathrm{ABC}$ proteins contain this "insert" in both NBDs. Other dissimilarities between the two NBDs of the $\mathrm{ABCC}$ subfamily members are found in sequences within the $\mathrm{ABC}$ signature regions and around the Walker $\mathrm{B}$ motifs.

The first sequence analysis of MRP1 indicated that this protein is not a canonical $\mathrm{ABC}$ transporter because the predicted membrane topology of the TMDs was peculiar. Although a common TMD1-NBD1-TMD2-NBD2 domain arrangement has been proposed, the $\mathrm{N}$ - and $\mathrm{C}$-terminal membrane-bound regions have been described as domains consisting of eight and four TMHs, respectively [24]. This topology model was challenged by limited proteolysis experiments and hydrophobicity analysis; consequently, a revised secondary structure for MRP1 has been proposed independently by two research groups [7, 149]. According to this new topology model, MRP1 has a domain arrangement of TMD0-L0-TMD1-NBD1-TMD2-NBD2, i.e., the $\mathrm{ABC}$ transporter "core region" is extended with an $\mathrm{N}$-terminal transmembrane domain (TMD0), which is connected to the core region with a characteristic intracellular linker region (L0). The three membrane-bound regions, TMD0, TMD1, and TMD2, consist of five, six, and another six TMHs, respectively (Fig. 1). Subsequent investigations introducing mutations to the glycosylation sites [49] and inserting hemagglutinin epitopes [67, 68] fully supported the latter membrane topology model. Furthermore, studies using an antibody against the $\mathrm{N}$ terminal 1-18 amino acids also confirmed the extracellular localization of the amino terminus of MRP1 [14].

The first but very limited set of structural data for MRP1 was obtained at $22 \AA$ resolution by electron microscopy of single particles of the purified protein [137]. The MRP1 monomer showed a pentagonal ring around a large pore. This ring exhibits a twofold pseudosymmetry, which may correspond to the core structure consisting of two TMDs and two NBDs. One of the two small dense regions, seen on the external side of the ring, might represent the TMD0 domain.

Although the TMD0 region is characteristic of several members of ABCC family, this domain was found to be dispensable for the function of MRP1. A truncated mutant, which lacks this domain, was functional with respect to transport activity, and similarly to the wild-type protein, localized to the basolateral membrane in polarized cells [6]. On the other hand, certain mutations in TMD0 resulted in significant conformational changes and reduced transport activity $[59,180]$. Based on these observations, it has been suggested that certain residues in TMD0 contribute to the maintenance of the correct structure of the protein. Recently, a detailed study investigating the influence of TMD0 on the subcellular localization of MRP1 revealed that, although TMD0 is not essential for basolateral trafficking of MRP1, deletion of the TMD0 region affects the subcellular distribution of the protein [169]. About 50\% of truncated protein was found in the recycling endosomes, whereas this was only $20 \%$ in the case of the intact MRP1. This finding suggests that TMD0 domain is important for the retention or the recycling of MRP1 to the plasma membrane. It has also been shown that both TMD0 and the remainder of the protein contain routing signals, and TMD0 becomes essential in trafficking when the $\mathrm{COOH}$-terminal region of MRP1 is mutated or truncated [169].
Fig. 1 Membrane topology model of MRP1. The depicted model was constructed on the basis of sequence analysis and the available experimental data (see text for details). TMD Transmembrane domain, $N B D$ nucleotide-binding domain, $L O$ linker region between TMD0 and TMD1. Mutations affecting substrate specificity and catalytic activity are indicated with red and blue marks, respectively

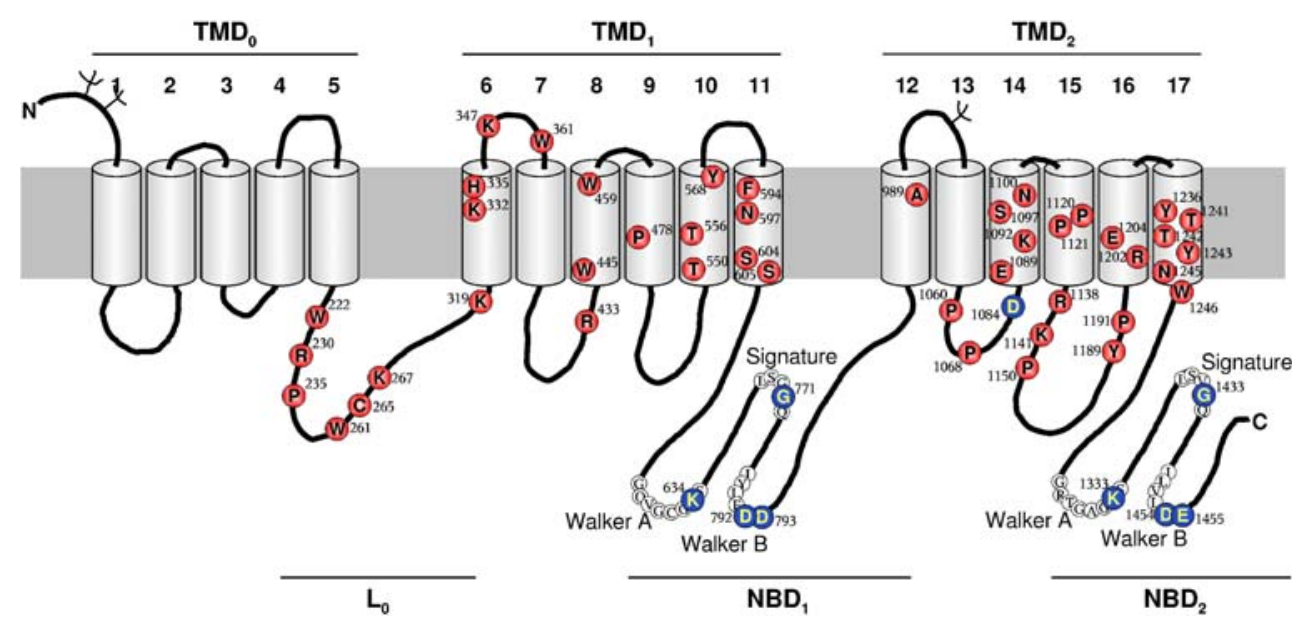


It is important to note that the TMD0 domains in other MRP1-related proteins, including the human MRP2 and yeast cadmium factor-1 (Ycf1), are required for correct apical targeting and for proper vacuolar localization, respectively [37, 98]. The TMD0 region of the human SUR1 anchors the protein to Kir6.2 potassium channel subunit. This interaction enhances their trafficking to the cell surface and supports the nucleotide-dependent gating of the channel [22].

In MRP1, the deletion of TMD0, together with the L0 linker region, abrogates the activity of the pump and causes its accumulation in intracellular membranes, indicating that the L0 domain is essential for function and proper trafficking [6]. Coexpression of the L0 peptide with the inactive core region results in restored activity and basolateral targeting of the transporter, suggesting that L0 forms a distinct domain that works in specific interaction with the core region of MRP1 [4]. The region in L0 responsible for the proper basolateral trafficking was mapped between amino acids 208 and 270, whereas the region of L0 required for transport activity falls between amino acids 208 and 260 [170]. Photoaffinity labeling and mutational studies implicated contribution of the L0 region to the formation of substrate-binding site because the L0 region was required for the binding of photoreactive analogs of certain characteristic substrates (see below) [126, 130, 170].

Surprisingly, the isolated L0 peptide, which was predicted to localize in the cytoplasm, was found to be attached to membranes [4]. Despite the relatively low sequence similarity, the proposed secondary structure of the L0 regions seems to be conserved in all members of the ABCC family. In accordance with the secondary structure predictions, the L0 region contains two helices, one of which is a characteristic amphipathic helix. This helix in MRP1 (amino acids 221-233) is responsible for the interaction with cell membranes because elimination of this helix abolishes membrane attachment of L0 [4]. In CFTR, an acidic cluster in the second helix of L0 was shown to interact with the R (regulatory) domain, which controls the channel activity [106]. In the case of MRP1, the nature of the interaction between the L0 linker region and the core structure is yet to be clarified.

\section{Handling of substrates}

The substrates of MRP1, identified indirectly by cytotoxicity assays and substrate-stimulated ATPase measurements, as well as directly by cellular and vesicular transport studies, comprise a vast variety of hydrophobic compounds, organic anion conjugates, and anionic nonconjugated substances. Table 1 summarizes the most characteristic substrates of MRP1. The typical conjugate substrates
Table 1 Selected substrates of human MRP1

\begin{tabular}{|c|c|}
\hline Substrates & References \\
\hline \multicolumn{2}{|l|}{ Conjugates } \\
\hline \multicolumn{2}{|l|}{ Endobiotic conjugates } \\
\hline \multicolumn{2}{|l|}{ GSH conjugates } \\
\hline Leukotriene $\mathrm{C}_{4}$, leukotriene $\mathrm{D}_{4}$, leukotriene $\mathrm{E}_{4}$ & {$[60,80,102]$} \\
\hline Prostaglandin $\mathrm{A}_{2}$-SG & {$[35]$} \\
\hline Hydroxynonenal-SG & {$[132]$} \\
\hline \multicolumn{2}{|l|}{ Glucuronide conjugates } \\
\hline Estradiol-17- $\beta$-D-glucuronide & {$[60,85]$} \\
\hline Glucuronosylbilirubin & {$[61]$} \\
\hline \multicolumn{2}{|l|}{ Sulfate conjugates } \\
\hline Estrone 3-sulfate, & [127] \\
\hline Dehydroepiandrosterone 3-sulfate & {$[60]$} \\
\hline Sulfatolithocholyl taurine & {$[60]$} \\
\hline \multicolumn{2}{|l|}{ Xenobiotic conjugates } \\
\hline \multicolumn{2}{|l|}{ GSH conjugates } \\
\hline Aflatoxin $\mathrm{B}_{1}$-epoxide-SG & [89] \\
\hline Chlorambucil-SG, melphalan-SG & [9] \\
\hline \multicolumn{2}{|l|}{ Glucuronide conjugates } \\
\hline $\begin{array}{l}\text { 4-(Methylnitrosamino)-1-(3-pyridyl)-1-butanol } \\
\text { (NNAL)-O-glucuronide }\end{array}$ & {$[84]$} \\
\hline \multicolumn{2}{|l|}{ Therapeutic agents } \\
\hline \multicolumn{2}{|l|}{ Anticancer drugs } \\
\hline \multicolumn{2}{|l|}{ Anthracyclines } \\
\hline Daunorubicin, doxorubicin & {$[25,45,133]$} \\
\hline \multicolumn{2}{|l|}{ Plant alkaloids } \\
\hline Vinblastine, vincristine, SN-38, etoposide & {$[25,45,87]$} \\
\hline \multicolumn{2}{|l|}{ Others } \\
\hline Methotrexate & {$[52]$} \\
\hline Antiandrogens (flutamide) & {$[46]$} \\
\hline \multicolumn{2}{|l|}{ HIV protease inhibitors } \\
\hline Saquinavir, ritonavir & {$[115]$} \\
\hline \multicolumn{2}{|l|}{ Other compounds } \\
\hline \multicolumn{2}{|l|}{ Metalloids } \\
\hline Sodium arsenite, potassium antimonite & {$[25,58]$} \\
\hline \multicolumn{2}{|l|}{ Peptides } \\
\hline GSH, GSSG & {$[79,87]$} \\
\hline$N$-acetyl-Leu-Leu-norleucinal (ALLN) & {$[31]$} \\
\hline \multicolumn{2}{|l|}{ Fluorescent probes } \\
\hline Calcein-AM, calcein & {$[51]$} \\
\hline $\mathrm{BCECF}$ & {$[33]$} \\
\hline
\end{tabular}

include glutathione, glucuronate, and sulfate conjugates, such as the cysteinyl leukotriene $\mathrm{LTC}_{4}$ [80, 102], estradiol$17-\beta$-D-glucuronide $\left(\mathrm{E}_{2} 17 \beta \mathrm{G}\right)[60,85]$, estrone 3 -sulfate [127], and sulfated bile acids [60]. The ability of MRP1 to transport glutathione conjugates and the expression of this protein in numerous tissues make MRP1 a ubiquitous glutathione-conjugate pump.

MRP1 can confer resistance not only to many commonly used neutral natural product chemotherapeutic agents $[25$, 45], like MDR1/P-glycoprotein, but also to various anionic compounds, such as the folic acid antimetabolite, methotrexate [52], certain heavy metal oxyanions (arsenical, 
antimonial) [25, 58], and antiandrogens (flutamide) [46]. Contrary to the MDR1/P-glycoprotein, the MRP1-mediated active transport of unmodified chemotherapeutic drugs, as well as that of certain anionic conjugates, requires the presence of glutathione (GSH). The mechanism by which GSH participates in MRP1-mediated efflux is rather complex. The transport of some hydrophobic agents, such as vincristine, is stimulated by GSH, and conversely, these compounds stimulate GSH transport [87]. This crossstimulation was originally explained by the cotransport of the two compounds, although a recent review by Borst et al. [15] suggests a mechanism of mutual heterotropic cooperativity of substrate-binding sites. On the other hand, glutathione stimulates the transport of certain substrates, but these compounds have no effect on GSH transport. These are exemplified by estrone 3-sulfate, 4-(methylnitrosamino)-1-(3-pyridyl)-1-butanol-O-glucuronide (NNAL-Oglucuronide), or daunorubicin [84, 127, 133]. In contrast to these substrates, certain compounds, such as verapamil and bioflavonoids, are not transported by MRP1 but they enhance the MRP1-mediated transport of GSH $[82,88]$.

To identify the regions of MRP1, which are directly involved in substrate binding, photoaffinity labeling studies and mutational analyses have been performed. The GSHdependent azidoagosterol A labeling of the protein was detected only in TMD2 [130], whereas the azido analogs of GSH and unconjugated drugs, such as rhodamine123, or quinoline, labeled both halves of MRP1, reacting with TMHs $10-11$ in TMD1 and TMHs 16-17 in TMD2 [29, $65,126]$. The iodoarylazido analog of $\mathrm{LTC}_{4}$ labeled the above two regions as well as TMH 12 [66], while the labeling with unmodified $\mathrm{LTC}_{4}$ showed that the TMHs 6, 7 , 10 , and 17 are parts of the $\mathrm{LTC}_{4}$ binding site [176].

As mentioned earlier, the $\mathrm{L} 0$ region has also been shown to participate in substrate binding. Removal of the L0 region, together with TMD0, abolished the binding of $\mathrm{LTC}_{4}$ or a photoaffinity analog of glutathione (azidophenacylGSH). The GSH-dependent binding of azidoagosterol A was also eliminated, although direct labeling of the L0 peptide with these compounds could not be demonstrated $[126,130,170]$. In contrast, the binding of azidoaryl derivative of glutathione to the L0 linker region has been detected [65]. Typical substrates, which are transported as glutathione or glucuronide conjugates, e.g., $\mathrm{LTC}_{4}$ or $\mathrm{E}_{2} 17 \beta \mathrm{G}$, are not transported by an MRP1 variant mutated in the L0 region (W222L, W223L, R231A, W261A, $\mathrm{K} 267 \mathrm{M})$. In contrast, the transport of an unconjugated substrate (SN38) was not affected in this variant [108]. These observations suggest that L0 participates in the formation of the site interacting with glutathione or glucuronide moieties. A photoaffinity analog of $\mathrm{LTC}_{4}$ also labeled the TMD0 domain; however, considering the fact that MRP1 lacking TMD0 is fully functional, it is more likely that TMD0 region does not directly contribute to the binding site of $\mathrm{LTC}_{4}$, and this region was labeled due to its close proximity to the photoreactive group [66].

A molecular model of MRP1 indicated that five residues of TMHs 10,11, 16, and 17 form an "aromatic basket", lining the putative substrate translocation pathway [20]. Mutational analyses demonstrated that amino acid changes affecting substrate specificity are found in almost all TMHs of TMD1, TMD2, as well as in the L0 region (for a review, see the work of Haimeur et al. [47]). However, these mutations are located predominantly in TMHs 11 and 17 and in the cytoplasmic loop connecting TMH 15 and TMH 16 (see Fig. 1).

Many substrates cross-inhibit the transport of one another, whereas several mutations inhibiting the transport of certain substrates have no effect on the transport of other substrates. These data indicate that these substrates bind to a common substrate-binding pocket and make contacts with overlapping but nonidentical sets of residues. In addition to the GSH-dependent transport, in some other cases, substrate-stimulated transports have also been observed. These include the cross-stimulation of the transport of $\mathrm{LTC}_{4}$ and estrone 3-sulfate at low concentrations [127], the acceleration of $\mathrm{LTC}_{4}$ transport by NNAL-O-glucuronide [84], and the stimulation of $\mathrm{N}$-ethylmaleimide glutathione transport by indomethacin at low concentrations [5]. These observations suggest the existence of more than one allosterically cooperative, nonoverlapping substrate-binding sites within the large substrate-binding pocket. At low concentration, various substrates can bind to distinct substrate-binding sites, facilitating the binding and transport of one another, whereas at higher concentrations, they saturate all the available binding sites and, thus, cross-inhibit the transport of one another.

\section{Catalytic cycle of MRP1}

As mentioned above, the transport of MRP1, similar to that of most $\mathrm{ABC}$ transporters, is driven by ATP binding/ hydrolysis. Unlike P-type ATPases, ABC transporters do not form phosphorylated intermediates during their transport cycle. To characterize the individual steps of the catalytic cycle, such as ATP binding, formation of the transition state, cleavage of the terminal phosphate bond (ATP hydrolysis), and release of ADP and phosphate, various experimental approaches are used. ATP binding is often examined by photoaffinity labeling under nonhydrolytic conditions by using azido-ATP. The transition-state complex formation can be followed by the so-called "nucleotide trapping" measurement. This also means photoaffinity labeling with azido-ATP but under hydrolytic conditions in the presence of a phosphate-mimicking anion, 
e.g., vanadate $[43,53,105]$. This anion stabilizes the transition-state complex $\left(\mathrm{MRP} 1 \cdot \mathrm{Mg} \cdot \mathrm{ADP} \cdot \mathrm{P}_{\mathrm{i}}\right)$ by replacing the gamma phosphate and arrests the transporter in this state. Another approach to characterize the individual steps of the ATPase cycle is the vanadate-catalyzed photooxidative cleavage reaction [69]. This method is based on the observation that the cleavage of the polypeptide chain upon UV irradiation in the presence of vanadate depends on the conformation of the protein. Thus, the ATP binding and the transition-state complex formation can be assessed by the accumulation of various cleavage products generated under nonhydrolytic and hydrolytic conditions, respectively. The full catalytic cycle, which also includes ATP hydrolysis and ADP/phosphate release, can be followed by ATPase measurements, determining the rate of phosphate liberation [5].

The scheme of the catalytic cycle of the ABC transporters is further complicated by the fact that these proteins contain two cooperating NBDs. In a number of bacterial ABC proteins, the NBDs and TMDs are expressed as separate proteins, which associate to form a functional unit. The analysis of the solved structures of dimeric NBDs of MJ0796, HlyB, MalK, and Rad50, as well as the studies on the structures of "complete" $\mathrm{ABC}$ transporters, which also contain the TMDs (BtuCD and MsbA), demonstrated that the two NDBs dimerize in a head-to-tail orientation and form two composite ATP-binding sites/catalytic sites [118]. In these dimeric arrangements, the Walker A of one NBD and the $\mathrm{ABC}$ signature motif of the other NBD are involved in the formation of an ATP-binding site. For simplicity, we subsequently refer to an active site in NDB1 or NBD2, which includes Walker A and Walker B of the respective NBD.

Both vanadate-induced cleavage reactions and azidoATP labeling experiments resulted in the conclusion that both NBDs bind ATP, although NBD1 has higher affinity for ATP than NBD2 [43, 53, 69, 178]. Nucleotide trapping has also been shown in both catalytic sites, but the rate of the transition-state complex formation was greater in NBD2 than in NBD1 $[43,53,105]$. These observations imply that both sites are catalytically active, but the hydrolytic activity of NBD2 is higher than that of NBD1.

The two NBDs of MDR1/P-glycoprotein are functionally equivalent, and the integrity of both NBDs is needed for transport. Inactivation of any one of the two ATP-binding sites results in the complete loss of trapping activity of the protein [101]. In contrast, chemical modifications or mutations of the consensus motifs in the two NBDs of MRP1 have different effects on the transport [43, 53, 121, 178]. Mutations of key residues in the Walker A or Walker $\mathrm{B}$ of NBD1 decreased $\mathrm{LTC}_{4}$ transport activity to $30-50 \%$ of the wild-type protein, whereas the corresponding mutations in NBD2 essentially inactivated the protein $[43,53,121]$.
On the other hand, substitution of the conserved Gly in the $\mathrm{ABC}$ signature sequence of NBD1 for Ala completely inactivates the protein, while this mutation in NDB2 causes only a partial inactivation [121].

Unambiguous evidence for allosteric interactions between NBD1 and NBD2 has been provided by azido-ATP labeling experiments, demonstrating that binding of ATP at NBD1 increases the affinity for ATP and ADP trapping at NBD2 [54]. Conversely, the trapping of ADP at NBD2 has also been shown to enhance the ATP binding at NBD1 in one report [53], while other studies indicated that mutations affecting nucleotide binding and trapping at NDB2 had no effect on ATP binding at NBD1 [43, 121].

Collectively, the different properties of nucleotide binding and transition-state complex formation of the individual NBDs, the diverse consequences of mutations in these domains, as well as their different allosteric regulation implicate distinguishable activities and functions for the two NBDs of MRP1. The data detailed above suggest that ATP binding to both NBDs and the hydrolysis at the NBD2 are the key steps for MRP1-mediated transport. Although ATP is also hydrolyzed at NBD1, the significance of this hydrolysis in the transport is unknown. It is interesting to note that Yang et al. [179] and Zhao and Chang [184] found that certain mutations in the NBD1 decreased the affinity for ATP but increased the transport activity. They interpreted their data in a way that the dissociation rate of nucleotide from the mutated variants of NBD1 is higher than that of wild type, and they concluded that the transport is promoted by the release of the bound nucleotide from NBD1 regardless of ATP hydrolysis. Similar functional asymmetry of NBDs has been shown in CFTR, where ATP binding to both NBDs is required for channel opening, while hydrolysis at NBD2 is necessary for the channel closing [12].

From among the several sequence differences between the NBDs of MRP1, the only one which was established to contribute to the observed functional differences is the putative catalytic base following the Walker B motifs [122]. This residue is Asp in NBD1 and Glu in NBD2. An Asp to Glu mutation in NBD1 enhanced the hydrolytic activity of NBD1, whereas the corresponding mutation of Glu to Asp decreased the rate of hydrolysis at NBD2 and the rate of ADP release. These observations suggest that the presence of Asp in this position is partially responsible for the low hydrolytic activity of NBD1.

It has been documented that purified MRP1 reconstituted in proteoliposomes as well as MRP1 in isolated insect cell membranes shows ATPase activity, which is stimulated by certain transported substrates of MRP1 [5, 97]. However, the mechanism by which transported substrates promote ATP hydrolysis is controversial. Gao et al. [43] found that $\mathrm{LTC}_{4}$ increased the binding of azido-ATP to NBD1 several 
folds, whereas it had little effect on nucleotide binding to NBD2. In contrast, others have found that $\mathrm{LTC}_{4}$ enhanced ATP binding to NBD2 but not to NBD1 [131]. These data differ from those obtained previously from nucleotide trapping studies on MDR1/P-glycoprotein [154] and recently from vanadate cleavage experiments with MRP1 [69]. These studies demonstrated that the transported substrates have no effect on nucleotide binding but accelerate the formation of the transition-state complex in both catalytic sites, suggesting that substrates stimulate a reaction step of the hydrolytic cycle after ATP binding but precede the formation of the transition-state complex. In accordance with this observation, the trapping of azidoADP was found to be enhanced by $\mathrm{LTC}_{4}$ at both NBDs [43]. The discrepancy considering the effect of substrates on ATP binding may be due to the fact that the experiments were performed in two different systems: azido-ATP labeling was done with coexpressed N-half and C-half of MRP1, while vanadate cleavage was done with the fulllength wild-type protein.

It has been commonly accepted that during the transport cycle of $\mathrm{ABC}$ transporters, the substrate binds to a highaffinity binding site, which is subsequently reoriented, and its substrate binding affinity becomes reduced, facilitating the release of the substrate. High- and low-affinity drug binding states of MRP1 were also distinguished. Either ATP with or without vanadate, or the poorly hydrolyzable ATP analog, ATP $\gamma \mathrm{S}$, can result in the transition from a high- to a low-affinity state [121]. Prolonged binding of either ATP or ADP in NBD2 effectively locked the protein in a low-affinity substrate binding state, while increased ADP trapping in NBD1 prevented this transition [122]. Based on these observations, it has been proposed that occupancy of both NBDs with ATP results in the formation of a low-affinity drug binding state, which persists until NDB2 is occupied with ADP. Manciu et al. [96] have characterized the structural changes of MRP1 during transport by using protease accessibility and infrared spectroscopy. They have demonstrated that ATP binding induces conformational changes in TMDs and increases the accessibility of the protein toward the aqueous medium, while no additional change in the conformational state of TMHs takes place upon ATP hydrolysis. These findings indicate that ATP binding rather than the hydrolysis drives the major structural reorganization in MRP1. However, in the case of a bacterial $\mathrm{ABC}$ transporter, the $\mathrm{MsbA}$, a recent electron paramagnetic resonance spectroscopic study has shown that the accessibility of the protein further increases at the external side upon the formation of the high-energy ADP-bound intermediate [32].

Taking together the structural and biochemical data discussed above, as well as the observed conformational changes during the catalytic cycle, the following transport model can be proposed. First, the substrate binds to its high-affinity binding site and MgATP binds to NBD1. Binding of ATP at NBD1 promotes the ATP binding to NBD2. ATP binding results in the formation of a closed dimer NBD conformation, and the subsequent conformational changes cause reconfiguration of the TMDs, resulting in lowering the affinity of the substrate binding site. A closed dimerization of NBDs allows the transition-state complex formation at NDB2. This causes a further conformational change, which results in getting the lowaffinity substrate-binding site even more exposed to the extracellular medium, and the substrate becomes released. The step which follows the ATP binding and leads to the transition-state complex formation is accelerated by the presence of substrates. After ATP hydrolysis, the terminal phosphate and subsequently ADP are released from NBD2. There are three options at this point to restart the transport cycle: (1) the protein returns to the high-affinity substratebinding state after ATP hydrolysis at NBD1 and ADP release, (2) the recovery takes place subsequent to the release of nonhydrolyzed ATP from NBD1, or (3) the protein is capable of binding of another substrate molecule without releasing the ATP from NBD1.

Substrate binding and ATP hydrolysis are promoted by different segments of the protein. However, the substratestimulated ATP hydrolysis and the ATP-energized substrate translocation require intramolecular interactions between the two halves of the protein. Studies on the structure of the MsbA transporter [134] revealed that the intracellular loop between TMH 2 and TMH 3 of this protein (ICD1), which consists of three helices in a U-like configuration, establishes contacts between the TMD and the NBD. The position of ICD1 makes feasible that this region is part of the pathway transmitting the conformational changes between the NBDs and the substrate-binding pocket. The corresponding first cytoplasmic loops in TMD1 and TMD2 of MRP1 have the same predicted architecture as the ICD1 in MsbA. Mutation of Asp 1084 in one of these loops in MRP1 drastically decreased nucleotide trapping at NBD2 and prevented the transition from high- to low-affinity state of protein, whereas ATP binding was unaffected [182]. These findings suggest that this intracellular region contributes to the transduction of conformational changes in MRP1, triggered by nucleotide binding and hydrolysis. However, the structural changes introduced into this loop by replacement of two prolines with alanines had no effect on the overall transport activity of the protein [71].

A recent study from our laboratory suggests that the ABC signature motif is a candidate for intramolecular communication [157]. The structures of ATP-bound NBD dimers show that the conserved second Gly residue in the $\mathrm{ABC}$ signature motif interacts with the oxygen of the gamma-phosphate of the ATP, bound to the Walker motif of 
the opposite subunit [118]. Substitution of these glycines for aspartic acids in either NBDs of MRP1 eliminates transport activity, but the mutants are still capable of forming the transition-state complex [157]. It is interesting to note that in these mutants, the formation of the intermediate complex is inhibited by substrates, whereas it is accelerated in the wild-type protein. Based on these results, we suggested that substrate binding facilitates the signature region to turn toward the ATP molecule bound to the opposing NDB. This movement allows the formation of the proper dimer interface for ATP hydrolysis. When a critical residue is mutated in this region, the characteristic substrate-induced conformational change is altered, implicating that the movement of the signature region is at the endpoint of the substrate-induced allosteric changes, and this region is a key component of the coupling of substrate binding and ATP hydrolysis. Similar observations have been made with the MDR1/P-glycoprotein [156].

\section{Regulation of MRP1 expression and function}

MRP1 expression is a subject of multiple regulatory mechanisms. In some multidrug resistant cell lines that overexpress MRP1, the MRP1 gene is amplified, while in others, an increased transcription occurs without gene amplification. The 5'-end region of MRP1 gene was cloned, and the analysis of this region showed that, similar to other human multidrug transporters, MRP1 has a TATA-less promoter [186]. The basal promoter activity was localized to nucleotides -91 to +103 in a GC-rich region of the MRP1 gene. There are putative Sp1 binding sites in the GC elements, and it was demonstrated that $\mathrm{Sp} 1$ in fact interacts with these binding sites, which were proven to be essential for optimal MRP1 transcriptional activity [187].

High-level MRP1 expression was observed even in tumors originating from tissues, which originally exhibit little MRP1 expression. This elevation in MRP1 expression is likely due to the upregulation by components that are involved in malignant transformation, such as oncogenes and tumor suppressor proteins. The wild-type p53 tumor suppressor protein has been shown to repress the transcription of MRP1 partially by deactivation of promoter-bound $\mathrm{Sp} 1$, whereas mutant $\mathrm{p} 53$ abrogates the repression of MRP1 [168]. Therefore, a loss of p53 function and/or an increase in $\mathrm{Sp} 1$ activity in tumor cells could contribute to an upregulation of the MRP1 gene, as demonstrated in various tumor types including prostate [153] and nonsmall-cell lung cancer (NSCLC) [117]. The MRP1 promoter contains a putative AP-1 site ( -498 through -492$)$, which interacts with a complex, containing c-jun and junD oncogenes [75]. Accordingly, downregulation of MRP1 expression has been found in cells transfected with mutant c-jun [27].
Numerous chemotherapeutic agents, including doxorubicin [144] and vinblastine [141], as well as heavy metals such as arsenite, cadmium, and mercury [58, 70], have been reported to induce MRP1 expression. In addition, reactive oxygen species (ROS) have been found to regulate the expression of MRP1. High intracellular ROS levels induce MRP1 expression, whereas the elevation in GSH concentration lowers the ROS levels and consequently results in downregulation of MRP1 [177]. Prooxidants, such as menadione, tert-butylhydroquinone, 2,3-dimethoxy-1,4naphthoquinone [177], and sulindac [161], which produce ROS and generate oxidative stress, have been shown to induce the expression of MRP1. It has been clearly demonstrated that the nuclear factor-E2 p45-related factor $2\left(\mathrm{Nrf}_{2}\right)$, the key transcriptional factor of antioxidant responsive element-driven genes [48], is involved in the regulation of MRP1 expression.

Similar to MRP1, another oxidative stress-sensitive gene product, the heavy subunit of $\gamma$-glutamylcysteine synthetase $(\gamma$-GCSh), which is the rate-limiting enzyme in glutathione biosynthesis, frequently shows elevated expression in many drug-resistant cell lines. Expressions of MRP1 and $\gamma$-GCSh are coinduced by many cytotoxic and redox active agents [58, 161]. Coordinated elevation in GSH production and in MRP1 pump activity ensures the effective extrusion of these toxic compounds by an MRP1-mediated, GSH-dependent transport mechanism. In addition, the expression of MRP1 and $\gamma-G C S h$ genes can also be upregulated by interleukin- $1 \beta$ through generation of nitric oxide, which is easily converted to reactive nitrogen species, reminiscent of ROS [56].

The mechanism underlying the concerted regulation of the MRP1 and $\gamma$-GCSh genes is unknown. Several oxidative stress-responsive elements, located upstream from the promoter of the MRPI and the $\gamma$-GCSh genes, have been identified [186]. One possibility is that these putative cis-acting elements mediate the oxidative stress-induced expression by interacting with redox-sensitive transcription factors. On the other hand, it has recently been demonstrated that doxorubicin upregulates the transcription of MRPI gene via doxorubicin-activated c-jun $\mathrm{N}$-terminal kinase (JNK), which enhances the association of the activated form of c-jun with the AP-1 site in the MRP1 promoter [144]. Moreover, stimulation of JNK activity has been observed upon depletion of intracellular GSH. These results, together with the finding that $\gamma-G C S h$ gene also contains an AP-1 binding site, implicate that c-jun/AP-1 may play a role in the coregulated expression of MRP1 and $\gamma$-GCSh.

Very little is known about the posttranslational regulations of MRP1. This transporter is extensively glycosylated, but either the transport function or the localization is not significantly modulated by protein glycosylation 
[7, 103]. MRP1 has been shown to be phosphorylated primarily on serine residues. Initially, it has been proposed that phosphorylation by protein kinase $\mathrm{C}$ (PKC) plays a role in the regulation of transport function of MRP1 because PKC inhibitors blocked MRP1-mediated transport [93]. However, this result might reflect a direct interaction of PKC inhibitors with MRP1 instead of a regulation through protein phosphorylation.

\section{Tissue distribution and subcellular localization}

In contrast to MRP2 and MRP3, which exhibit a rather constrained tissue distribution, MRP1 is ubiquitously expressed in the body. The tissues showing the highest level of MRP1 expression include the lung, testis, kidney, heart, and placenta, whereas a moderate MRP1 expression was found in the small intestine, colon, brain, and peripheral blood mononuclear cells [24, 42, 116, 123]. Because most of these tissues belong to the defense lines of the body, it is somewhat unexpected that MRP1 is expressed at a very low level in the liver, the major organ of xenobiotic metabolism and detoxification. It is interesting to note that MRP1 expression is elevated in the regenerating regions of the liver after tissue damage [136]. Because animal models are often used for pharmacokinetic studies, it is noteworthy that certain differences in tissue distribution of MRP1 can be seen among various species, e.g., the canine liver shows a relatively high expression of
MRP1, whereas, as mentioned earlier, in the normal human liver, MRP1 expression is hardly detectable [26, 42]. Gender differences in MRP1 expression in the kidney and liver have also been reported, i.e., higher MRP1 expressions were found in female mice [94].

In tissues where MRP1 is expressed at a relatively high level, the transporter is not distributed uniformly but primarily expressed in special cell types. Table 2 summarizes the cell-type-specific expression pattern of MRP1 in various tissues. In general, cells with a specialized barrier function or cells at a high proliferative status exhibit higher expression of MRP1 than the surrounding cell types. The former is exemplified by the choroid cells in the blood cerebrospinal fluid barrier [129], or the syncytiotrophoblasts and fetal blood-vessel endothelial cells in the placenta [147], whereas the latter notion is demonstrated by the reactive type II pneumocytes in hyperplastic alveoli of the lung [17], or the crypt Paneth cells in the small intestine [123]. The increased level of MRP1 expression in the reactive ductules of the damaged liver is explained by the activation of hepatic progenitor cells [136], which also represent a rapidly multiplying cell type. Similarly, the increase in MRP1 expression during culturing of brain microvessel isolates can be a consequence of the presence of a cell subpopulation with higher proliferative potential [143].

With respect to subcellular localization, MRP1 is primarily expressed in the plasma membrane [41, 181]. Immunocytochemical studies demonstrated basolateral lo-

Table 2 Cell type-specific distributions of MRP1

\begin{tabular}{|c|c|c|c|}
\hline Tissues & High MRP1 expression & $\begin{array}{l}\text { No/low MRP1 } \\
\text { expression }\end{array}$ & References \\
\hline Lung & $\begin{array}{l}\text { Bronchial epithelial cells, bronchiolar epithelial cells, } \\
\text { seromucinous glands, reactive type II pneumocytes, } \\
\text { alveolar macrophages }\end{array}$ & $\begin{array}{l}\text { Normal type I and II } \\
\text { alveolar pneumocytes }\end{array}$ & {$[17,42,140,175]$} \\
\hline Testis & $\begin{array}{l}\text { Sertoli cells in the seminiferous tubules, Leydig cells, } \\
\text { testosterone-producing interstitial cells outside } \\
\text { the seminiferous tubules }\end{array}$ & & {$[42,163,173]$} \\
\hline Kidney & $\begin{array}{l}\text { Glomeruli, ascending limb cells, epithelial cells of the } \\
\text { loop of Henle, distal and collecting duct cells }\end{array}$ & Proximal tubule cells & {$[123,173]$} \\
\hline Placenta & $\begin{array}{l}\text { Fetal blood vessels of the terminal and intermediate villi, } \\
\text { syncytiotrophoblasts, epithelial cells of the endoplacental } \\
\text { yolk sac }\end{array}$ & & {$[104,146,147]$} \\
\hline $\begin{array}{l}\text { Small } \\
\text { intestine }\end{array}$ & Crypt cells (Paneth cells) & Enterocytes & {$[123]$} \\
\hline Colon & Entire crypt-villous axis & & [123] \\
\hline \multirow[t]{3}{*}{ Brain } & Brain capillary endothelial cell & & {$[107,143,151,183]$} \\
\hline & $\begin{array}{l}\text { Choroidal and ependymal cells, tanycytes in the } \\
\text { choroid plexus }\end{array}$ & & {$[129,171]$} \\
\hline & Glial cells, parenchyma astrocytes & & {$[28,44]$} \\
\hline Blood & Erythrocytes, T-cells, mast cells & & {$[10,111,116,125,172]$} \\
\hline
\end{tabular}


calization for MRP1 in various polarized cell types, including drug-selected and transfected cells as well as epithelial and endothelial cells of normal tissues [17, 36, 83, 123, 140, 175]. In contrast, other $\mathrm{ABC}$ transporters which are thought to be crucial in tissue defense, such as MDR1/P-glycoprotein, MRP2, and ABCG2, reside in the apical membrane of polarized cells [19, 95, 162]. The relative position of MRP1 and these transporters in selected tissues is depicted in Fig. 2. Surprisingly, MRP1 was found to localize to the apical surface of the brain capillary endothelial cells $[107,151,183]$. Thus, the ipsilateral distribution of MRP1 with MDR1/P-glycoprotein, MRP2, and ABCG2 in the brain vessels represents an exception. Contradicting data have been published on the subcellular localization of MRP1 in the placental trophoblasts. Initial reports suggested apical localization [146]; however, more recent studies revealed that this transporter localizes to the basolateral membrane of syncytiotrophoblasts [104, 147].

In addition to the plasma membrane localization, intracellular expression of MRP1 has been found in various cell lines [3, 24, 44, 128, 167] and normal tissue samples $[42,174]$. The subcellular organelles where MRP1 accumulation was seen include endocytic vesicles [3], perinuclearly located lysosomes [128], and trans-Golgi vesicles $[44,167]$. The role of intracellular MRP1 is yet to be clarified. Because MRP1-dependent accumulation of fluorescent drugs into these organelles was also demonstrated
[128, 167], it has been proposed that, in addition to extruding drugs through the plasma membrane, MRP1 can confer drug-resistant phenotype to cells by sequestering the drugs into the intracellular compartments. This suggestion would resolve the contradiction how a drug-resistant cell line expressing MRP1 may exhibit the same level of intracellular drug accumulation as its drug-sensitive counterpart [24]. Because these studies were performed with cells overexpressing the transporter and/or with MRP1 tagged with fluorescent proteins, for the evaluation of the physiological relevance of these observations, it should be considered that either overexpression or tagging may greatly influence the subcellular localization pattern. However, the predominant cytoplasmic expression of MRP1 seen in several normal tissues $[42,174]$ indicates that the intracellular localization of the transporter might have a physiological role. The interesting finding that MRP1 rapidly translocates from the Golgi to the plasma membrane in response to unconjugated bilirubin exposure [44] suggests that intracellularly expressed MRP1 serves as a cellular reservoir, which can be easily mobilized and targeted to the site of action. The particular trafficking signals directing MRP1 to the plasma membrane, as well as the retention and recycling mechanisms determining the further cellular routing of the transporter, are not known yet. However, certain regions such as the L0 domain $[4,6$, 170], and the C-terminus in cooperation with the TMD0 [169], were found to be crucial for proper targeting.
Fig. 2 Cell-type-specific expression and subcellular localization of MRP1 in various physiological barriers. The figure illustrates the relative position of MRP1 and other selected $\mathrm{ABC}$ transporters (MDR1/Pglycoprotein, ABCG2, and MRP2) at the blood-brain barrier (a), the blood-cerebrospinal fluid barrier (b), the placenta (c), and the blood-testis barrier (d). MRP1 is expressed in the basolateral membrane of the ventricular epithelial cells in the choroid plexus, the syncytiotrophoblasts in the placenta, and the Sertoli cells in the seminiferous tubules. In contrast, MRP1 is localized to the apical membrane of the brain capillary endothelial cells, ipsilaterally to MDR1/P-glycoprotein, ABCG2, and MRP2. MRP1 is also expressed in the fetal blood vessels in the placenta and in the testosterone-producing Leydig cells in the testis

\section{a}

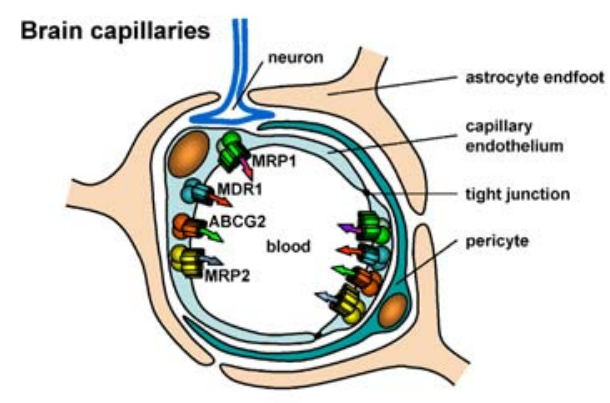

C

Placenta

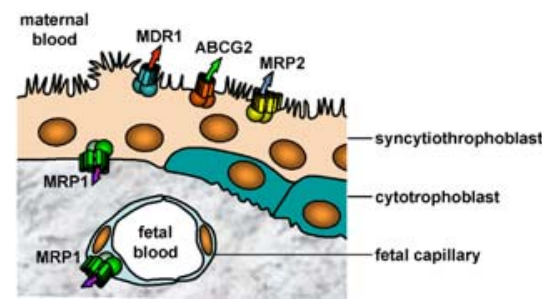

b

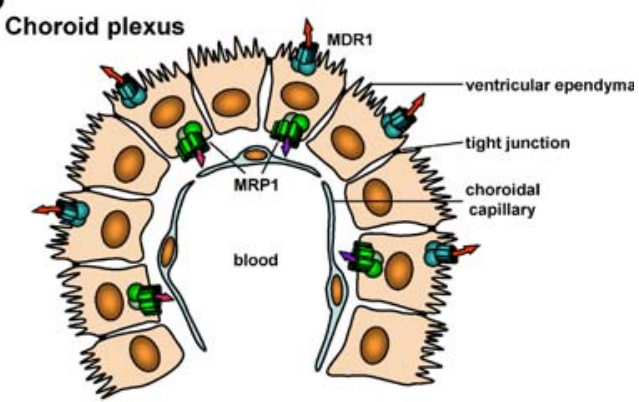

d

Testis

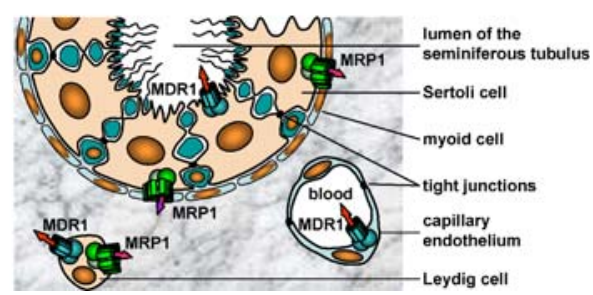




\section{Dual role of MRP1 in the physiological barriers}

The substrate specificity of MRP1, together with its distribution in tissues which are considered as the major defense lines of the body, implies a physiological role for MRP1 in protection against xenobiotics and endogenous toxic metabolites (endobiotics). The cellular detoxification process comprises four stages: the uptake of the toxic compounds (phase 0), followed by oxidation (phase I) and conjugation with an anionic group (phase II), and finally, the conjugates are extruded from the cells in an ATPdependent manner (phase III). MRP1 and related proteins were suggested to play a role in this terminal step of detoxification [57].

Unambiguous verification for this function of MRP1 has emerged from studies using knockout animals. Mice deficient in mrp1 (mrp1 (-/-)) were independently generated by two groups and found to be viable, healthy, and fertile with normal histological and hematological parameters [92, 172]. Challenging the knockout animals with etoposide (VP-16), however, revealed that the mrp1 (-/-) mice are hypersensitive to this cytotoxic drug. The affected tissues include bone marrow, oropharyngeal mucosa, Sertoli cells in the seminiferous tubules of the testis, and urinary collecting tubules in the kidney $[92,173]$. Similarly, developing spermatocytes and spermatids were damaged in the testis of mrp1 (-/-) mice after a treatment with the pesticide methoxychlor [163].

Although numerous in vitro studies clearly demonstrated the MRP1-mediated transport of various xeno- and endobiotics, several attempts failed to prove this protective role of MRP1 in vivo. Constitutive expression of MRP1 failed to protect mice from the toxic effect of arsenical and antimonial compounds [90]. The carcinogenicity of aflatoxin B1 in the mrp1 (-/-) mice was not different from that seen in wild-type animals [91]. Similarly, the permeation of several drugs and conjugates across the blood-brain barrier and the blood-cerebrospinal fluid barrier was unaffected in the mrp1-deficient mice [23, 76]. These data were explained by the presence of other transporters which also contribute to these defense mechanisms and can compensate for the lack of MRP1. This explanation is rather plausible because numerous transmembrane export pumps with partially overlapping substrate specificities are present and highly expressed in the physiological barriers. The $\mathrm{ABC}$ transporters which are thought to play a crucial role in detoxification and tissue defense include MDR1/P-glycoprotein, MRP1, MRP2, and ABCG2 (for recent review, see the paper of Leslie et al. [83]).

More compelling results were obtained from studies combining different single knockouts and/or using multiple knockout animals. In mice deficient in mdrla, mdrlb, and mrp1, vincristine and etoposide were found to be toxic to the bone marrow and the gastrointestinal mucosa [62], indicating their compensatory role in protection against these drugs. By using different knockout animals, the role of mrpl in the tissue distribution and excretion of grepafloxacin, a new quinolone antibiotic, has also been demonstrated [139]. Contribution of MRP1 to bloodcerebrospinal fluid barrier was unambiguously shown by comparing the etoposide levels in the blood-cerebrospinal fluid in mdr1a/mdrlb double and $\mathrm{mdr} 1 \mathrm{a} / \mathrm{mdr} 1 \mathrm{~b} / \mathrm{mrp} 1$ triple knockout mice after intravenous administration of this compound [171]. Similarly, the protective function of mrp1 in the blood-brain barrier was demonstrated by the decreased elimination rate of estradiol-17- $\beta$-D-glucuronide from the brain of the triple knockout mice [151].

With the exception of brain capillary endothelial cells, in most physiological barriers, MRP1 is expressed in the basolateral membrane of polarized cells, contralaterally to MDR1/P-glycoprotein, MRP2, and ABCG2 (see Fig. 2). This subcellular distribution confers a function for MRP1 distinct from that of the other efflux pumps. In the first line defense fronts of the body, in the lung and the gut, the primary task of the protective efflux system is the removal of toxic compounds back to the lumen. In the airway and intestinal epithelial cells, however, the transport of MRP1 is contrary to the luminal extrusion $[123,140]$. Similarly, in the kidney and the liver, which are the major sites of elimination of xeno- and endobiotics, MRP1, when expressed, is facing the serosal side, opposite to the direction of excretion [123, 136]. Thus, it has been proposed that the role of MRP1 in these tissues is protecting the special, sensitive cell types from toxic effects of xeno- and endobiotics rather than the elimination of these compounds from the body [83]. This concept is supported by the note that a high level of MRP1 expression was observed in cells at a high proliferative status, such as hyperplastic reactive type II pneumocytes in the lung [17], Paneth cells in the small intestine [123], and hepatic progenitor cells in the damaged liver [136] (see above).

On the other hand, the role of MRP1 in the blood-tissue barriers seems to be different. As verified by the studies using mrp1-deficient mice, this transporter greatly contributes to the barrier function, protecting the various sanctuary sites of the body. Both in the blood-brain barrier and the choroid plexus, MRP1 is expressed at the serosal side, i.e., the apical surface of brain capillary [107, 151, 183], and the basolateral membrane of the ventricular epithelial (choroidal and ependymal) cells [129, 171], respectively. Thus, transport activity of MRP1 prevents the accumulation of toxins in the brain and cerebrospinal fluid by extruding these compounds into the blood. In the placenta, MRP1 is primarily expressed in the abluminal (basolateral) side of fetal vessel endothelial cells $[104,146]$ and in the epithelial cells of the endoplacental yolk sac [147]. This localization 
brings about the protection of the fetus by limiting the entry and "quarantining" the toxic compounds. In contrast, the low-level expression of MRP1 found in the basolateral membrane of syncytiotrophoblasts rather serves as a defense system for the trophoblast itself or possibly mediates the transport of important metabolites across the maternal-fetal interface [83, 104]. In accordance with this notion, an increase in MRP1 expression can be observed with placental maturation $[120,147]$. In the testis, MRP1 most probably plays a role in the local defense, protecting the special cell types such as the Sertoli cells and the developing spermatocytes in the seminiferous tubules. This suggestion has emerged from the observation that etoposide or methoxychlor exposure damaged primarily these cells in the testes of mrp1 $-/-$ mice $[163,173]$. A special role for MRP1 has been proposed in the testosterone-producing Leydig cells, where the transporter is expressed at a high level $[42,173]$. Because this cell type is the major site of estrogen conjugation in the testis, and estrogen conjugates are known as high-affinity MRP1 substrates, it is not implausible to assume that MRP1 plays a role in protecting the testis from the feminizing effect of estrogens [127].

\section{The role of MRP1 in leukotriene metabolism and oxidative stress defense}

In addition to exogenous and endogenous toxic compounds, the inflammatory cytokine $\mathrm{LTC}_{4}$ and its metabolites $\mathrm{LTD}_{4}$ and $\mathrm{LTE}_{4}$ were also identified as MRP1 substrates $[80,86]$. These cysteinyl leukotrienes are known to increase vascular permeability and smooth-muscle contraction at the site of inflammation. $\mathrm{LTC}_{4}$ is synthesized from $\mathrm{LTA}_{4}$ by conjugation with GSH in leukotrienegenerating cells such as mast cells, macrophages, basophilic and eosinophilic granulocytes, dendritic cells, and platelets. $\mathrm{LTC}_{4}$ is released from these cells in an ATP-dependent manner and rapidly converted extracellularly to $\mathrm{LTD}_{4}$ and $\mathrm{LTE}_{4}$ by $\gamma$-glutamyltranspeptidase and dipeptidase, respectively. Because numerous photoaffinity labeling and vesicular transport studies have demonstrated that $\mathrm{LTC}_{4}$ is one of the highest affinity MRP1 substrates [60, 80, 86, 102], it has been postulated that this transporter is responsible for the cellular release of $\mathrm{LTC}_{4}$ from the leukotriene-producing cells. This hypothesis attributes an additional physiological function to MRP1, which greatly differs from its role in protecting special, sensitive cell types and sanctuary sites of the body.

Unambiguous evidence for the role of MRP1 in the leukotriene-mediated inflammatory responses was provided by studies with the mrp1 (-/-) mice. Bone marrow-derived mast cells isolated from the knockout animals exhibited only a minor residual $\mathrm{LTC}_{4}$ release, which was accompa- nied by an intracellular accumulation of this cytokine [172]. This observation clearly demonstrated MRP1 as the major efflux pump for $\mathrm{LTC}_{4}$ in mast cells. Even more compelling are the observations showing impaired immune reactions in the mrp1 (-/-) mice. The response to arachidonic acid, a leukotriene-inducing inflammatory stimulus, was greatly reduced in the mrp1-deficient mice as measured by decreased ear edema and vascular permeability, whereas the responses to topical application of phorbol ester (prostaglandin-induced inflammatory stimulus) or to intradermal injection of $\mathrm{LTC}_{4}$ were unaffected [172].

The mobilization of dendritic cells from the skin to the lymph nodes was also found to be greatly reduced in the mrp1 knockout animals, whereas this defect was overcome by the exogenous administration of cysteinyl leukotrienes $\left(\mathrm{LTC}_{4}\right.$ and $\left.\mathrm{LTD}_{4}\right)$, demonstrating the crucial role of MRP1 in the $\mathrm{LTC}_{4}$ release [135]. Surprisingly, mrp1 (-/-) mice were found to be more resistant to Streptococcus pneumoniae-induced pneumonia than wild-type animals [142]. This observation also connects MRP1 with leukotriene metabolism. As a consequence of the lack of mrp1, intracellular $\mathrm{LTC}_{4}$ is accumulated in the leukotriene-producing cells, which results in the accumulation of $\mathrm{LTA}_{4}$, a common precursor for $\mathrm{LTC}_{4}$ and $\mathrm{LTB}_{4}$. Thus, $\mathrm{LTA}_{4}$ becomes more available for conversion to $\mathrm{LTB}_{4}$. This suggestion is supported by the observations that (1) $\mathrm{LTB}_{4}$ concentration was elevated in the bronchoalveolar lavage fluid of the mrp1 (-/-) mice; (2) $\mathrm{LTB}_{4}$-dimethyl amide, an $\mathrm{LTB}_{4}$ antagonist, abolished the survival advantage of knockout animals; (3) peritoneal macrophages of mrp1 (-/-) mice produce more $\mathrm{LTB}_{4}$ than macrophages from wild-type mice in response to arachidonic acid or heat-killed S. pneumoniae. Collectively, these studies with mrp1 (-/-) mice firmly established the intimate involvement of MRP1 in the leukotriene metabolism.

Several elements of the transcriptional regulation of MRP1 gene, such as oxidative stress-responsive elements of its promoter region [186] and regulation of expression by Nrf2 [48] and by ROS [161, 177], implicate a connection between this transporter and the redox state of the cell. At a high oxidative state, the cell abolishes the toxic effect of peroxides by their reduction using glutathione (GSH) as an electron donor, producing glutathione disulfide (GSSG). GSH is normally recycled by GSSG reductase enzyme, but during oxidative stress, GSSG is also released from several cell types via an overflow system. Implicating an involvement of MRP1 in the GSH/GSSG metabolism, in the mrp1 $(-/-)$ mice, increased accumulation of GSH was found in tissues which normally express MRP1, whereas GSH concentration was unchanged in tissues known to express little MRP1 [92].

Reduced glutathione was proven to be a poor substrate of MRP1 [79, 87], but its transport is stimulated by 
bioflavonoids and verapamil by increasing the apparent affinity of the transporter for GSH [82, 88]. In contrast, GSSG by itself was found to be a substrate with an apparent $K_{\mathrm{m}}$ value of around $100 \mu \mathrm{M}$ [79]. This affinity makes MRP1 capable of extruding GSSG from cell during oxidative stress when the activity of GSSG reductase becomes rate limiting. Although overexpression of MRP1 failed to increase resistance against oxidative stress in transfected cell lines [8], endogenously expressed MRP1 was shown to mediate cellular GSSG release in response to oxidative stress in astrocytes and endothelial cells [50, 100]. The specificity in these studies was demonstrated by blocking the GSSG efflux by the MRP1 inhibitor MK571 or by MRP1 siRNA. Further support was provided by the findings that the elevated endothelial GSSG efflux observed in the aorta of hypertensive mice was blocked by MK571 and was absent in hypertensive mrp1 (-/-) mice [100]. In addition to its role in the GSSG efflux, MRP1 also contributes to defense against oxidative stress by removal of GS conjugates formed in the cells at a high oxidative state. This is most well exemplified by 4-hydroxynonenal, the predominant toxic lipid peroxidation product, which was found to be bound to and transported by MRP1 [132]. In summary, MRP1 seems to be a multifunctional efflux pump, which not only functions as a part of a defense system against xenobiotics and toxic metabolites but also contributes to immunological responses and to the elimination of toxic effects caused by oxidative stress.

\section{The pathophysiological aspect of MRP1}

In addition to its diverse physiological functions, there is a significant body of evidence that MRP1 also contributes to the clinical MDR of several hematological and solid tumors. The MDR phenotype was described in drugselected tumor cell lines, which exhibited cross-resistance to a wide range of structurally and functionally unrelated anticancer agents. With regard to the mechanism, it has been generally accepted that MDR is a consequence of the presence and activity of export pumps with broad substrate specificity. These transporters extrude cytotoxic agents from the cells, maintaining the drug level below a cellkilling threshold. Several ABC transporters, including MDR1/P-glycoprotein, MRP1-6, ABCG2, MRP7-8, MDR3 (ABCB4), sPgp (ABCB11), and ABCA2, have been shown to confer drug resistance for cell lines in vitro; however, their involvement in the clinical MDR has been established only for MDR1/P-glycoprotein, MRP1, and ABCG2.

As mentioned earlier, MRP1 was originally cloned from a doxorubicin-selected lung cancer cell line, which exhibited resistance to a range of cytotoxic agents without increased expression of MDR1/P-glycoprotein [24]. The substrate specificity of MRP1, as assessed in initial transport measurements with inside-out vesicles, did not correlate with the drug resistance profile found in cell lines. Most of these discrepancies were resolved by the findings that several drugs are transported by MRP1 as glutathione or glucuronide conjugates or require GSH for their transport. The former is exemplified by chlorambucil-GS, melphalan-GS, or etoposide-glucuronide $[9,60]$, while the latter is represented by vincristine and daunorubicin $[86$, 87, 133]. Overexpression of MRP1 has been found in numerous drug-selected cell lines derived from various tumors, including lung cancers, breast cancer, gastric and colon carcinomas, prostate cancer, melanoma, neuroblastoma and glioma, fibrosarcoma and epidermoid carcinoma, as well as diverse types of leukemias. Unlike MRP1-enriched inside-out vesicles, these cellular model systems most likely possess all the features, such as glutathione or the drugconjugating apparatus, which are conceivably needed for effective transport. However, the MRP1-conferred drug resistance profiles found in these cell lines were still dissimilar. This variability was observed not only in cell lines with different origin but also in cells derived from the same parental cell line [30, 145], implicating that the MDR phenotype is multifactorial and possibly involves other resistance factors such as DNA-topoisomerases, cytochrome P450 enzymes, and other ABC transporters capable of conferring drug resistance. Consistent with this idea, several reports indicated that overexpression of MDR1/Pglycoprotein followed MRP1 overexpression in sequential selection procedures $[18,145,185]$. Thus, for a better evaluation of drug resistance in cell lines, a more complex approach is required. Recently, a novel pharmacogenomic method was introduced by Szakacs et al. [155], determining expression profiles for the entire human $\mathrm{ABC}$ transporter panel in 60 various cancer cell lines (NCI-60) and correlating them with the growth inhibitory profile of about 1,500 potential anticancer drugs.

To circumvent the problems deriving from multifactorial cellular responses to selective pressure of drug exposure, cell lines transfected with MRP1 cDNA have been generated to investigate MRP1-conferred MDR [3, 25, 45, 181]. These studies revealed similar drug resistance profiles in transfected cells of various origins, although minor differences still existed. In general, the transfectants exhibited increased resistance to doxorubicin, daunorubicin, epirubicine, vincristine, and etoposide (VP-16) but not to cisplatin, taxol, and mitoxantrone. Colchicine and vinblastine resistance conferred by MRP1 slightly varied from cell line to cell line. In addition to these "classical" anticancer agents, resistance to methotrexate [52], ethacrynic acid [99], arsenical and antimonial oxyanions [25], as well as to cytotoxic peptides such as ALLN and 4A6 
[31] was observed in MRP1-transfected cells. Not only the drug resistance of these cells but also reduced intracellular accumulation and increased efflux of cytotoxic agents have been shown $[25,36,52,181]$. After cloning the murine and rat orthologs of human MRP1, some remarkable species differences have been revealed. Cells transfected with mouse or rat mrp1 did not exhibit resistance to anthracyclines; furthermore, rat mrp1-transfected cells also remained sensitive to vinca alkaloids [148, 159]. These species differences call our attention to a careful interpretation of pharmacological studies using these animal models.

Although the cellular model systems are powerful tools to investigate the MDR phenotype conferred by MRP1, the clinical relevance of MRP1 in human malignancies was established by studies investigating the expression and/or function of MRP1 in clinical samples. Increased level of MRP1 expression has been found in a wide range of hematological and solid tumors (for references, see Table 3). Some of them, such as nonsmall-cell lung cancer (NSCLC) $[13,109,150,175]$ or chronic lymphoblastic leukemia [63, 111], generally exhibit high level of MRP1 expression and these tumors are intrinsically multidrug resistant, whereas others such as small-cell lung cancer (SCLC) [175], gastric carcinoma [2, 34], neuroblastoma [114], and retinoblastoma [21] exhibit high MRP1 expression with a lower frequency. A correlation between the MRP1 expression and the stage of the tumor has been reported in certain tumor types, such as acute myeloblastic leukemia (AML) [165], myelodysplastic syndromes (MDS) [124], and prostate cancer [153]. On the other hand, in lung adenocarcinomas, a reverse correlation was seen with tumor grading [13]. High MRP1 expression was also found to be associated with higher

Table 3 Tumor types with elevated MRP1 expression

\begin{tabular}{ll}
\hline Tumor types & References \\
\hline Acute myeloblastic leukemia (AML) & {$[77,78,124,165]$} \\
Acute lymphoblastic leukemia (ALL) & {$[11]$} \\
Chronic lymphoblastic leukemia (CLL) & {$[63,111]$} \\
Nonsmall-cell lung cancer (NSCLC) & {$[13,73,109,150$,} \\
& $175]$ \\
Small-cell lung cancers (SCLC) & {$[13,73,175]$} \\
Breast cancer & {$[38,110,138]$} \\
Prostate cancer & {$[152,164]$} \\
Gastric carcinoma & {$[2,34]$} \\
Esophageal squamous cell carcinoma (ESCC) & {$[112,160]$} \\
Colorectal cancer & {$[40,160]$} \\
Endometrial carcinoma & {$[72]$} \\
Glioma & {$[1]$} \\
Neuroblastoma & {$[113,114]$} \\
Retinoblastoma & {$[21]$} \\
\hline
\end{tabular}

grade of tumor differentiation in digestive tract carcinomas [160], endometrial carcinomas [72], and various subtypes of NSCLC, such as lung adenocarcinoma and squamous cell carcinoma [109, 150].

In numerous cases, elevated MRP1 expression was found to be associated with transcriptional regulation events. Because p53 is a suppressor of MRP1 transcription [168], it is not surprising that a strong correlation between mutant p53 status and MRP1 expression was found in prostate cancer [153] and NSCLC [117]. Similarly, an association between the expression of MRP1 and the Nmyc oncogen has been firmly established in neuroblastoma $[114,119]$. Increased MRP1 expression was observed after chemotherapy in relapsed SCLC [73], bladder carcinomas [158], and acute lymphoblastic leukemia (ALL) [11]. Whether this is a consequence of repopulation of drugresistant cells (selection) or upregulation of expression in response to drug exposure (induction) remains to be established.

Various clinical parameters, e.g., overall survival, eventfree survival, responsiveness to chemotherapy, etc., were correlated with MRP1 expression to explore its contribution to clinical drug resistance. Many of these studies failed to establish a causative role for MRP1 in the negative disease outcome, whose failure is mainly attributable to the impediments hindering this kind of investigations. One of these difficulties is the fact that MRP1 is expressed in almost all normal tissues, and contamination of tumor samples with variable amounts of normal tissues can lead to ambiguous results. Another factor, which can also complicate the interpretation of the results of such studies, is the possible presence of other drug resistance-associated proteins, e.g., LRP/MVP or MDR1/P-glycoprotein. Moreover, the drug extrusion activity of the transporter is not necessarily proportional to the amount of mRNA or protein, especially at high levels of expression. Therefore, definitive conclusions can be obtained only from carefully designed and performed multiparametric studies, which include the identification of the tumor cells, detection of alternative resistance-associated proteins, and use of a specific functional assay, whenever possible.

The significance of this issue is clearly demonstrated by the example of acute myeloblastic leukemia (AML). Several independent studies indicated that MRP1 expression is not predictive of negative therapy outcome in AML [39, 81, 124]. However, when MDR1/P-glycoprotein and MRP1 were assessed together by an appropriate functional assay, the activity of the multidrug transporters was proven to be a negative prognostic factor for achievement of complete remission [64, 77, 78, 166]. Despite all these difficulties discussed above, MRP1 expression has been found to be predictive of poor response to chemotherapy in NSCLC $[13,117]$ and SCLC 
$[55,74]$. Similarly, MRP1 positivity was strongly associated with reduction in both overall survival and event-free survival in breast cancer [38, 110] and neuroblastoma $[113,114,119]$. In addition, a strong correlation between MRP1 expression and shorter times to relapse has been found in breast cancer [38, 110, 138].

Because MDR represents a major obstacle to cancer treatment, the observations discussed above emphasize the significance of MRP1 with respect to clinical practice. Enormous efforts have been made to develop chemotherapeutics and modulators (reversing agents) to prevent MDR (for recent review, see the work of Boumendjel et al. [16]). However, application of modulators is a doubleedged sword because these agents may abolish the physiological barriers or result in inhibition of other essential physiological functions of these transporters. Consequently, a more complex approach for better therapy achievements should include a proper, multiparametric diagnosis comprising the selective detection of all possible drug-resistance proteins, as well as a personalized therapeutic intervention that takes into consideration of the results of such diagnosis.

\section{Conclusions}

Since the identification of MRP1, considerable amount of experimental data accumulated on the structure, transport function, substrates, cosubstrates, and inhibitors of this transporter. Still, "we see in a mirror dimly" regarding the transport mechanism due to the complexity and the puzzling details of the transport cycle. Although MRP1 has been originally identified as an alternative multidrug transporter in drug-selected cell lines, it turned out to be a protein with multiple physiological functions. Generation and detailed investigation of knockout animals brought a breakthrough in understanding of the diverse physiological roles of MRP1, although these studies were also hampered by the compensatory effects of other $\mathrm{ABC}$ transporters with a substrate specificity partially overlapping that of MRP1. Collectively, according to our current understanding, this transporter (1) protects special cell types from the toxic effects of xeno- and endobiotics; (2) contributes to the barrier function of the defense lines of certain sanctuary sites of the body; (3) participates in leukotriene-mediated inflammatory responses through $\mathrm{LTC}_{4}$ transport; and (4) contributes to defense against oxidative stress by providing an overflow system for GSSG. In addition to these numerous beneficial functions, there is also a vicious aspect of this transporter. Namely, MRP1 has been proven to be responsible for clinical MDR in several human malignancies such as lung, breast, prostate cancer, pediatric tumors, and various forms of leukemia.
Acknowledgments The authors apologize from those whose valuable work was not cited in this review article for space limitations. We are grateful to Dr. Balázs Sarkadi and Dr. András Váradi for their advice and comments. Dr. George Gárdos and Dr. Tamás Orbán are acknowledged for their critical reading and corrections of this manuscript. We appreciate the support of research grants (OTKA AT 048729, NF 61822), which allowed us to compile this review. László Homolya is an EMBO-HHMI Young Scientist.

\section{References}

1. Abe T, Mori T, Wakabayashi Y, Nakagawa M, Cole SP, Koike K, Kuwano M, Hori S (1998) Expression of multidrug resistance protein gene in patients with glioma after chemotherapy. J Neurooncol 40:11-18

2. Alexander D, Yamamoto T, Kato S, Kasai S (1999) Histopathological assessment of multidrug resistance in gastric cancer: expression of P-glycoprotein, multidrug resistance-associated protein, and lung-resistance protein. Surg Today 29:401-406

3. Almquist KC, Loe DW, Hipfner DR, Mackie JE, Cole SP, Deeley RG (1995) Characterization of the M(r) 190,000 multidrug resistance protein (MRP) in drug-selected and transfected human tumor cell. Cancer Res 55:102-110

4. Bakos E, Hegedus T, Hollo Z, Welker E, Tusnady GE, Zaman GJ, Flens MJ, Varadi A, Sarkadi B (1996) Membrane topology and glycosylation of the human multidrug resistance-associated protein. J Biol Chem 271:12322-12326

5. Bakos E, Evers R, Szakacs G, Tusnady GE, Welker E, Szabo K, de Haas M, van Deemter L, Borst P, Varadi A, Sarkadi B (1998) Functional multidrug resistance protein (MRP1) lacking the Nterminal transmembrane domain. J Biol Chem 273:32167-32175

6. Bakos E, Evers R, Calenda G, Tusnady GE, Szakacs G, Varadi A, Sarkadi B (2000) Characterization of the amino-terminal regions in the human multidrug resistance protein (MRP1). J Cell Sci 113(Pt 24):4451-4461

7. Bakos E, Evers R, Sinko E, Varadi A, Borst P, Sarkadi B (2000) Interactions of the human multidrug resistance proteins MRP1 and MRP2 with organic anions. Mol Pharmacol 57:760-768

8. Balcerczyk A, Rychlik B, Kruszewski M, Burchell B, Bartosz G (2003) MRP1-transfected cells do not show increased resistance against oxidative stress. Free Radic Res 37:189-195

9. Barnouin K, Leier I, Jedlitschky G, Pourtier-Manzanedo A, Konig J, Lehmann WD, Keppler D (1998) Multidrug resistance protein-mediated transport of chlorambucil and melphalan conjugated to glutathione. Br J Cancer 77:201-209

10. Bartosz G, Konig J, Keppler D, Hagmann W (1998) Human mast cells secreting leukotriene $\mathrm{C} 4$ express the MRP1 geneencoded conjugate export pump. Biol Chem 379:1121-1126

11. Beck JF, Brugger D, Brischwein K, Liu C, Bader P, Niethammer D, Gekeler V (2001) Anticancer drug-mediated induction of multidrug resistance-associated genes and protein kinase $\mathrm{C}$ isozymes in the T-lymphoblastoid cell line CCRF-CEM and in blasts from patients with acute lymphoblastic leukemias. Jpn J Cancer Res 92:896-903

12. Berger AL, Ikuma M, Welsh MJ (2005) Normal gating of CFTR requires ATP binding to both nucleotide-binding domains and hydrolysis at the second nucleotide-binding domain. Proc Natl Acad Sci USA 102:455-460

13. Berger W, Setinek U, Hollaus P, Zidek T, Steiner E, Elbling L, Cantonati H, Attems J, Gsur A, Micksche M (2005) Multidrug resistance markers P-glycoprotein, multidrug resistance protein 1, and lung resistance protein in non-small cell lung cancer: prognostic implications. J Cancer Res Clin Oncol 131:355-363 
14. Binyamin L, Assaraf YG, Haus-Cohen M, Stark M, Reiter Y (2004) Targeting an extracellular epitope of the human multidrug resistance protein 1 (MRP1) in malignant cells with a novel recombinant single chain $\mathrm{Fv}$ antibody. Int $\mathrm{J}$ Cancer 110:882-890

15. Borst P, Zelcer N, van de Wetering K, Poolman B (2006) On the putative co-transport of drugs by multidrug resistance proteins. FEBS Lett 580:1085-1093

16. Boumendjel A, Baubichon-Cortay H, Trompier D, Perrotton T, Di Pietro A (2005) Anticancer multidrug resistance mediated by MRP1: recent advances in the discovery of reversal agents. Med Res Rev 25:453-472

17. Brechot JM, Hurbain I, Fajac A, Daty N, Bernaudin JF (1998) Different pattern of MRP localization in ciliated and basal cells from human bronchial epithelium. J Histochem Cytochem 46:513-517

18. Brock I, Hipfner DR, Nielsen BS, Jensen PB, Deeley RG, Cole SP, Sehested M (1995) Sequential coexpression of the multidrug resistance genes MRP and mdrl and their products in VP-16 (etoposide)-selected $\mathrm{H} 69$ small cell lung cancer cells. Cancer Res 55:459-462

19. Buchler M, Konig J, Brom M, Kartenbeck J, Spring H, Horie T, Keppler D (1996) cDNA cloning of the hepatocyte canalicular isoform of the multidrug resistance protein, cMrp, reveals a novel conjugate export pump deficient in hyperbilirubinemic mutant rats. J Biol Chem 271:15091-15098

20. Campbell JD, Koike K, Moreau C, Sansom MS, Deeley RG, Cole SP (2004) Molecular modeling correctly predicts the functional importance of Phe594 in transmembrane helix 11 of the multidrug resistance protein, MRP1 (ABCC1). J Biol Chem 279:463-468

21. Chan HS, Lu Y, Grogan TM, Haddad G, Hipfner DR, Cole SP, Deeley RG, Ling V, Gallie BL (1997) Multidrug resistance protein (MRP) expression in retinoblastoma correlates with the rare failure of chemotherapy despite cyclosporine for reversal of P-glycoprotein. Cancer Res 57:2325-2330

22. Chan KW, Zhang H, Logothetis DE (2003) N-terminal transmembrane domain of the SUR controls trafficking and gating of Kir6 channel subunits. EMBO J 22:3833-3843

23. Cisternino S, Rousselle C, Lorico A, Rappa G, Scherrmann JM (2003) Apparent lack of Mrp1-mediated efflux at the luminal side of mouse blood-brain barrier endothelial cells. Pharm Res 20:904-909

24. Cole SP, Bhardwaj G, Gerlach JH, Mackie JE, Grant CE, Almquist KC, Stewart AJ, Kurz EU, Duncan AM, Deeley RG (1992) Overexpression of a transporter gene in a multidrug-resistant human lung cancer cell line. Science 258: $1650-1654$

25. Cole SP, Sparks KE, Fraser K, Loe DW, Grant CE, Wilson GM, Deeley RG (1994) Pharmacological characterization of multidrug resistant MRP-transfected human tumor cells. Cancer Res 54:5902-5910

26. Conrad S, Viertelhaus A, Orzechowski A, Hoogstraate J, Gjellan K, Schrenk D, Kauffmann HM (2001) Sequencing and tissue distribution of the canine MRP2 gene compared with MRP1 and MDR1. Toxicology 156:81-91

27. Cripe LD, Gelfanov VM, Smith EA, Spigel DR, Phillips CA, Gabig TG, Jung SH, Fyffe J, Hartman AD, Kneebone P, Mercola D, Burgess GS, Boswell HS (2002) Role for c-jun N-terminal kinase in treatment-refractory acute myeloid leukemia (AML): signaling to multidrug-efflux and hyperproliferation. Leukemia 16:799-812

28. Dallas S, Zhu X, Baruchel S, Schlichter L, Bendayan R (2003) Functional expression of the multidrug resistance protein 1 in microglia. J Pharmacol Exp Ther 307:282-290
29. Daoud R, Julien M, Gros P, Georges E (2001) Major photoaffinity drug binding sites in multidrug resistance protein 1 (MRP1) are within transmembrane domains 10-11 and 16-17. J Biol Chem 276:12324-12330

30. David-Beabes GL, Overman MJ, Petrofski JA, Campbell PA, de Marzo AM, Nelson WG (2000) Doxorubicin-resistant variants of human prostate cancer cell lines DU 145, PC-3, PPC-1, and TSU-PR1: characterization of biochemical determinants of antineoplastic drug sensitivity. Int J Oncol 17:1077-1086

31. de Jong MC, Slootstra JW, Scheffer GL, Schroeijers AB, Puijk WC, Dinkelberg R, Kool M, Broxterman HJ, Meloen RH, Scheper RJ (2001) Peptide transport by the multidrug resistance protein MRP1. Cancer Res 61:2552-2557

32. Dong J, Yang G, McHaourab HS (2005) Structural basis of energy transduction in the transport cycle of MsbA. Science 308:1023-1028

33. Draper MP, Martell RL, Levy SB (1997) Active efflux of the free acid form of the fluorescent dye 2',7'-bis(2-carboxyethyl)-5(6)carboxyfluorescein in multidrug-resistance-protein-overexpressing murine and human leukemia cells. Eur J Biochem 243:219-224

34. Endo K, Maehara Y, Ichiyoshi Y, Kusumoto T, Sakaguchi Y, Ohno S, Sugimachi K (1996) Multidrug resistance-associated protein expression in clinical gastric carcinoma. Cancer 77:1681-1687

35. Evers R, Cnubben NH, Wijnholds J, van Deemter L, van Bladeren PJ, Borst P (1997) Transport of glutathione prostaglandin A conjugates by the multidrug resistance protein 1 . FEBS Lett 419:112-116

36. Evers R, Zaman GJ, van Deemter L, Jansen H, Calafat J, Oomen LC, Oude Elferink RP, Borst P, Schinkel AH (1996) Basolateral localization and export activity of the human multidrug resistance-associated protein in polarized pig kidney cells. J Clin Invest 97:1211-1218

37. Fernandez SB, Hollo Z, Kern A, Bakos E, Fischer PA, Borst P, Evers R (2002) Role of the N-terminal transmembrane region of the multidrug resistance protein MRP2 in routing to the apical membrane in MDCKII cells. J Biol Chem 277:31048-31055

38. Filipits M, Pohl G, Rudas M, Dietze O, Lax S, Grill R, Pirker R, Zielinski CC, Hausmaninger H, Kubista E, Samonigg H, Jakesz R (2005) Clinical role of multidrug resistance protein 1 expression in chemotherapy resistance in early-stage breast cancer: the Austrian Breast and Colorectal Cancer Study Group. J Clin Oncol 23:1161-1168

39. Filipits M, Suchomel RW, Zochbauer S, Brunner R, Lechner K, Pirker R (1997) Multidrug resistance-associated protein in acute myeloid leukemia: no impact on treatment outcome. Clin Cancer Res 3:1419-1425

40. Fillpits M, Suchomel RW, Dekan G, Stiglbauer W, Haider K, Depisch D, Pirker R (1997) Expression of the multidrug resistance-associated protein (MRP) gene in colorectal carcinomas. Br J Cancer 75:208-212

41. Flens MJ, Izquierdo MA, Scheffer GL, Fritz JM, Meijer CJ, Scheper RJ, Zaman GJ (1994) Immunochemical detection of the multidrug resistance-associated protein MRP in human multidrugresistant tumor cells by monoclonal antibodies. Cancer Res 54 : $4557-4563$

42. Flens MJ, Zaman GJ, van der Valk P, Izquierdo MA, Schroeijers AB, Scheffer GL, van der Groep P, de Haas M, Meijer CJ, Scheper RJ (1996) Tissue distribution of the multidrug resistance protein. Am J Pathol 148:1237-1247

43. Gao M, Cui HR, Loe DW, Grant CE, Almquist KC, Cole SP, Deeley RG (2000) Comparison of the functional characteristics of the nucleotide binding domains of multidrug resistance protein 1. J Biol Chem 275:13098-13108 
44. Gennuso F, Fernetti C, Tirolo C, Testa N, L'Episcopo F, Caniglia S, Morale MC, Ostrow JD, Pascolo L, Tiribelli C, Marchetti B (2004) Bilirubin protects astrocytes from its own toxicity by inducing up-regulation and translocation of multidrug resistanceassociated protein 1 (Mrp1). Proc Natl Acad Sci USA 101: $2470-2475$

45. Grant CE, Valdimarsson G, Hipfner DR, Almquist KC, Cole SP, Deeley RG (1994) Overexpression of multidrug resistanceassociated protein (MRP) increases resistance to natural product drugs. Cancer Res 54:357-361

46. Grzywacz MJ, Yang JM, Hait WN (2003) Effect of the multidrug resistance protein on the transport of the antiandrogen flutamide. Cancer Res 63:2492-2498

47. Haimeur A, Conseil G, Deeley RG, Cole SP (2004) The MRPrelated and $\mathrm{BCRP} / \mathrm{ABCG} 2$ multidrug resistance proteins: biology, substrate specificity and regulation. Curr Drug Metab 5:21-53

48. Hayashi A, Suzuki H, Itoh K, Yamamoto M, Sugiyama Y (2003) Transcription factor Nrf2 is required for the constitutive and inducible expression of multidrug resistance-associated protein 1 in mouse embryo fibroblasts. Biochem Biophys Res Commun 310:824-829

49. Hipfner DR, Almquist KC, Leslie EM, Gerlach JH, Grant CE, Deeley RG, Cole SP (1997) Membrane topology of the multidrug resistance protein (MRP). A study of glycosylationsite mutants reveals an extracytosolic NH2 terminus. J Biol Chem 272:23623-23630

50. Hirrlinger J, Konig J, Keppler D, Lindenau J, Schulz JB, Dringen R (2001) The multidrug resistance protein MRP1 mediates the release of glutathione disulfide from rat astrocytes during oxidative stress. J Neurochem 76:627-636

51. Hollo Z, Homolya L, Hegedus T, Sarkadi B (1996) Transport properties of the multidrug resistance-associated protein (MRP) in human tumour cells. FEBS Lett 383:99-104

52. Hooijberg JH, Broxterman HJ, Kool M, Assaraf YG, Peters GJ, Noordhuis P, Scheper RJ, Borst P, Pinedo HM, Jansen G (1999) Antifolate resistance mediated by the multidrug resistance proteins MRP1 and MRP2. Cancer Res 59:2532-2535

53. Hou Y, Cui L, Riordan JR, Chang X (2000) Allosteric interactions between the two non-equivalent nucleotide binding domains of multidrug resistance protein MRP1. J Biol Chem 275:20280-20287

54. Hou YX, Riordan JR, Chang XB (2003) ATP binding, not hydrolysis, at the first nucleotide-binding domain of multidrug resistance-associated protein MRP1 enhances ADP.Vi trapping at the second domain. J Biol Chem 278:3599-3605

55. Hsia TC, Lin CC, Wang JJ, Ho ST, Kao A (2002) Relationship between chemotherapy response of small cell lung cancer and Pglycoprotein or multidrug resistance-related protein expression. Lung 180:173-179

56. Ikegami Y, Tatebe S, Lin-Lee YC, Xie QW, Ishikawa T, Kuo MT (2000) Induction of MRP1 and gamma-glutamylcysteine synthetase gene expression by interleukin 1 beta is mediated by nitric oxide-related signalings in human colorectal cancer cells. J Cell Physiol 185:293-301

57. Ishikawa T (1992) The ATP-dependent glutathione S-conjugate export pump. Trends Biochem Sci 17:463-468

58. Ishikawa T, Bao JJ, Yamane Y, Akimaru K, Frindrich K, Wright CD, Kuo MT (1996) Coordinated induction of MRP/GS-X pump and gamma-glutamylcysteine synthetase by heavy metals in human leukemia cells. J Biol Chem 271: 14981-14988

59. Ito K, Weigl KE, Deeley RG, Cole SP (2003) Mutation of proline residues in the $\mathrm{NH}(2)$-terminal region of the multidrug resistance protein, MRP1 (ABCC1): effects on protein expression, membrane localization, and transport function. Biochim Biophys Acta 1615:103-114
60. Jedlitschky G, Leier I, Buchholz U, Barnouin K, Kurz G, Keppler D (1996) Transport of glutathione, glucuronate, and sulfate conjugates by the MRP gene-encoded conjugate export pump. Cancer Res 56:988-994

61. Jedlitschky G, Leier I, Buchholz U, Hummel-Eisenbeiss J, Burchell B, Keppler D (1997) ATP-dependent transport of bilirubin glucuronides by the multidrug resistance protein MRP1 and its hepatocyte canalicular isoform MRP2. Biochem J 327(Pt 1):305-310

62. Johnson DR, Finch RA, Lin ZP, Zeiss CJ, Sartorelli AC (2001) The pharmacological phenotype of combined multidrugresistance mdr1a/1b- and mrp1-deficient mice. Cancer Res 61: $1469-1476$

63. Juszczynski P, Niewiarowski W, Krykowski E, Robak T, Warzocha K (2002) Expression of the multidrug resistanceassociated protein (mrp) gene in chronic lymphocytic leukemia. Leuk Lymphoma 43:153-158

64. Karaszi E, Jakab K, Homolya L, Szakacs G, Hollo Z, Telek B, Kiss A, Rejto L, Nahajevszky S, Sarkadi B, Kappelmayer J (2001) Calcein assay for multidrug resistance reliably predicts therapy response and survival rate in acute myeloid leukaemia. Br J Haematol 112:308-314

65. Karwatsky J, Daoud R, Cai J, Gros P, Georges E (2003) Binding of a photoaffinity analogue of glutathione to MRP1 (ABCC1) within two cytoplasmic regions (L0 and L1) as well as transmembrane domains $10-11$ and $16-17$. Biochemistry 42 : 3286-3294

66. Karwatsky J, Leimanis M, Cai J, Gros P, Georges E (2005) The leucotriene $\mathrm{C} 4$ binding sites in multidrug resistance protein 1 (ABCC1) include the first membrane multiple spanning domain. Biochemistry 44:340-351

67. Kast C, Gros P (1998) Epitope insertion favors a six transmembrane domain model for the carboxy-terminal portion of the multidrug resistance-associated protein. Biochemistry 37 : 2305-2313

68. Kast C, Gros P (1997) Topology mapping of the amino-terminal half of multidrug resistance-associated protein by epitope insertion and immunofluorescence. J Biol Chem 272:26479-26487

69. Kern A, Szentpetery Z, Liliom K, Bakos E, Sarkadi B, Varadi A (2004) Nucleotides and transported substrates modulate different steps of the ATPase catalytic cycle of MRP1 multidrug transporter. Biochem J 380:549-560

70. Kim SH, Bark H, Choi CH (2005) Mercury induces multidrug resistance-associated protein gene through $\mathrm{p} 38$ mitogen-activated protein kinase. Toxicol Lett 155:143-150

71. Koike K, Conseil G, Leslie EM, Deeley RG, Cole SP (2004) Identification of proline residues in the core cytoplasmic and transmembrane regions of multidrug resistance protein 1 (MRP1/ABCC1) important for transport function, substrate specificity, and nucleotide interactions. J Biol Chem 279: $12325-12336$

72. Koshiyama M, Yoshida M, Fujii H, Konishi M, Nanno H, Hayashi M, Tauchi K (1999) Expression of multidrug resistance-associated protein in endometrial carcinomas: correlation with clinicopathology and prognosis. Ann Diagn Pathol 3:81-87

73. Kreisholt J, Sorensen M, Jensen PB, Nielsen BS, Andersen CB, Sehested M (1998) Immunohistochemical detection of DNA topoisomerase IIalpha, P-glycoprotein and multidrug resistance protein (MRP) in small-cell and non-small-cell lung cancer. Br J Cancer 77:1469-1473

74. Kuo TH, Liu FY, Chuang CY, Wu HS, Wang JJ, Kao A (2003) To predict response chemotherapy using technetium- $99 \mathrm{~m}$ tetrofosmin chest images in patients with untreated small cell lung cancer and compare with p-glycoprotein, multidrug resistance 
related protein-1, and lung resistance-related protein expression. Nucl Med Biol 30:627-632

75. Kurz EU, Cole SP, Deeley RG (2001) Identification of DNAprotein interactions in the $5^{\prime}$ flanking and $5^{\prime}$ untranslated regions of the human multidrug resistance protein (MRP1) gene: evaluation of a putative antioxidant response element/ AP-1 binding site. Biochem Biophys Res Commun 285:981990

76. Lee YJ, Kusuhara H, Sugiyama Y (2004) Do multidrug resistance-associated protein-1 and -2 play any role in the elimination of estradiol-17 beta-glucuronide and 2,4-dinitrophenyl-S-glutathione across the blood-cerebrospinal fluid barrier? J Pharm Sci 93:99-107

77. Legrand O, Simonin G, Beauchamp-Nicoud A, Zittoun R, Marie JP (1999) Simultaneous activity of MRP1 and Pgp is correlated with in vitro resistance to daunorubicin and with in vivo resistance in adult acute myeloid leukemia. Blood 94: 1046-1056

78. Legrand O, Zompi S, Perrot JY, Faussat AM, Benderra Z, Chaoui D, Marie JP (2004) P-glycoprotein and multidrug resistance associated protein-1 activity in 132 acute myeloid leukemias according to FAB subtypes and cytogenetics risk groups. Haematologica 89:34-41

79. Leier I, Jedlitschky G, Buchholz U, Center M, Cole SP, Deeley RG, Keppler D (1996) ATP-dependent glutathione disulphide transport mediated by the MRP gene-encoded conjugate export pump. Biochem J 314(Pt 2):433-437

80. Leier I, Jedlitschky G, Buchholz U, Cole SP, Deeley RG, Keppler D (1994) The MRP gene encodes an ATP-dependent export pump for leukotriene $\mathrm{C} 4$ and structurally related conjugates. J Biol Chem 269:27807-27810

81. Leith CP, Kopecky KJ, Chen IM, Eijdems L, Slovak ML, McConnell TS, Head DR, Weick J, Grever MR, Appelbaum FR, Willman CL (1999) Frequency and clinical significance of the expression of the multidrug resistance proteins MDR1/P-glycoprotein, MRP1, and LRP in acute myeloid leukemia: a Southwest Oncology Group Study. Blood 94:1086-1099

82. Leslie EM, Deeley RG, Cole SP (2003) Bioflavonoid stimulation of glutathione transport by the $190-\mathrm{kDa}$ multidrug resistance protein 1 (MRP1). Drug Metab Dispos 31:11-15

83. Leslie EM, Deeley RG, Cole SP (2005) Multidrug resistance proteins: role of P-glycoprotein, MRP1, MRP2, and BCRP (ABCG2) in tissue defense. Toxicol Appl Pharmacol 204: 216-237

84. Leslie EM, Ito K, Upadhyaya P, Hecht SS, Deeley RG, Cole SP (2001) Transport of the beta-O-glucuronide conjugate of the tobacco-specific carcinogen 4-(methylnitrosamino)-1-(3-pyridyl)1-butanol (NNAL) by the multidrug resistance protein 1 (MRP1). Requirement for glutathione or a non-sulfur-containing analog. J Biol Chem 276:27846-27854

85. Loe DW, Almquist KC, Cole SP, Deeley RG (1996) ATPdependent 17 beta-estradiol 17-(beta-D-glucuronide) transport by multidrug resistance protein (MRP). Inhibition by cholestatic steroids. J Biol Chem 271:9683-9689

86. Loe DW, Almquist KC, Deeley RG, Cole SP (1996) Multidrug resistance protein (MRP)-mediated transport of leukotriene $\mathrm{C} 4$ and chemotherapeutic agents in membrane vesicles. Demonstration of glutathione-dependent vincristine transport. J Biol Chem 271:9675-9682

87. Loe DW, Deeley RG, Cole SP (1998) Characterization of vincristine transport by the M(r) 190,000 multidrug resistance protein (MRP): evidence for cotransport with reduced glutathione. Cancer Res 58:5130-5136

88. Loe DW, Deeley RG, Cole SP (2000) Verapamil stimulates glutathione transport by the $190-\mathrm{kDa}$ multidrug resistance protein 1 (MRP1). J Pharmacol Exp Ther 293:530-538
89. Loe DW, Stewart RK, Massey TE, Deeley RG, Cole SP (1997) ATP-dependent transport of aflatoxin B1 and its glutathione conjugates by the product of the multidrug resistance protein (MRP) gene. Mol Pharmacol 51:1034-1041

90. Lorico A, Bertola A, Baum C, Fodstad O, Rappa G (2002) Role of the Multidrug Resistance Protein 1 in protection from heavy metal oxyanions: investigations in vitro and in MRP1-deficient mice. Biochem Biophys Res Commun 291:617-622

91. Lorico A, Nesland J, Emilsen E, Fodstad O, Rappa G (2002) Role of the multidrug resistance protein 1 gene in the carcinogenicity of aflatoxin B1: investigations using mrp1-null mice. Toxicology 171:201-205

92. Lorico A, Rappa G, Finch RA, Yang D, Flavell RA, Sartorelli AC (1997) Disruption of the murine MRP (multidrug resistance protein) gene leads to increased sensitivity to etoposide (VP-16) and increased levels of glutathione. Cancer Res 57:5238-5242

93. Ma L, Krishnamachary N, Center MS (1995) Phosphorylation of the multidrug resistance associated protein gene encoded protein P190. Biochemistry 34:3338-3343

94. Maher JM, Slitt AL, Cherrington NJ, Cheng X, Klaassen CD (2005) Tissue distribution and hepatic and renal ontogeny of the multidrug resistance-associated protein (Mrp) family in mice. Drug Metab Dispos 33:947-955

95. Maliepaard M, Scheffer GL, Faneyte IF, van Gastelen MA, Pijnenborg AC, Schinkel AH, van De Vijver MJ, Scheper RJ, Schellens JH (2001) Subcellular localization and distribution of the breast cancer resistance protein transporter in normal human tissues. Cancer Res 61:3458-3464

96. Manciu L, Chang XB, Buyse F, Hou YX, Gustot A, Riordan JR, Ruysschaert JM (2003) Intermediate structural states involved in MRP1-mediated drug transport. Role of glutathione. J Biol Chem 278:3347-3356

97. Mao Q, Leslie EM, Deeley RG, Cole SP (1999) ATPase activity of purified and reconstituted multidrug resistance protein MRP1 from drug-selected H69AR cells. Biochim Biophys Acta 1461:69-82

98. Mason DL, Michaelis S (2002) Requirement of the N-terminal extension for vacuolar trafficking and transport activity of yeast Ycflp, an ATP-binding cassette transporter. Mol Biol Cell 13:4443-4455

99. Morrow CS, Smitherman PK, Townsend AJ (1998) Combined expression of multidrug resistance protein (MRP) and glutathione S-transferase P1-1 (GSTP1-1) in MCF7 cells and high level resistance to the cytotoxicities of ethacrynic acid but not oxazaphosphorines or cisplatin. Biochem Pharmacol 56: 1013-1021

100. Mueller CF, Widder JD, McNally JS, McCann L, Jones DP, Harrison DG (2005) The role of the multidrug resistance protein-1 in modulation of endothelial cell oxidative stress. Circ Res 97:637-644

101. Muller M, Bakos E, Welker E, Varadi A, Germann UA, Gottesman MM, Morse BS, Roninson IB, Sarkadi B (1996) Altered drug-stimulated ATPase activity in mutants of the human multidrug resistance protein. J Biol Chem 271:1877-1883

102. Muller M, Meijer C, Zaman GJ, Borst P, Scheper RJ, Mulder $\mathrm{NH}$, de Vries EG, Jansen PL (1994) Overexpression of the gene encoding the multidrug resistance-associated protein results in increased ATP-dependent glutathione S-conjugate transport. Proc Natl Acad Sci USA 91:13033-13037

103. Muller M, Yong M, Peng XH, Petre B, Arora S, Ambudkar SV (2002) Evidence for the role of glycosylation in accessibility of the extracellular domains of human MRP1 (ABCC1). Biochemistry 41:10123-10132

104. Nagashige M, Ushigome F, Koyabu N, Hirata K, Kawabuchi M, Hirakawa T, Satoh S, Tsukimori K, Nakano H, Uchiumi T, Kuwano M, Ohtani H, Sawada Y (2003) Basal membrane 
localization of MRP1 in human placental trophoblast. Placenta 24:951-958

105. Nagata K, Nishitani M, Matsuo M, Kioka N, Amachi T, Ueda K (2000) Nonequivalent nucleotide trapping in the two nucleotide binding folds of the human multidrug resistance protein MRP1. J Biol Chem 275:17626-17630

106. Naren AP, Cormet-Boyaka E, Fu J, Villain M, Blalock JE, Quick MW, Kirk KL (1999) CFTR chloride channel regulation by an interdomain interaction. Science 286:544-548

107. Nies AT, Jedlitschky G, Konig J, Herold-Mende C, Steiner HH, Schmitt HP, Keppler D (2004) Expression and immunolocalization of the multidrug resistance proteins, MRP1-MRP6 (ABCC1ABCC6), in human brain. Neuroscience 129:349-360

108. Noguchi T, Ren XQ, Aoki S, Igarashi Y, Che XF, Nakajima Y, Takahashi H, Mitsuo R, Tsujikawa K, Sumizawa T, Haraguchi M, Kobayashi M, Goto S, Kanehisa M, Aikou T, Akiyama S, Furukawa T (2005) MRP1 mutated in the L0 region transports $\mathrm{SN}-38$ but not leukotriene $\mathrm{C} 4$ or estradiol-17 (beta-D-glucuronate). Biochem Pharmacol 70:1056-1065

109. Nooter K, Bosman FT, Burger H, van Wingerden KE, Flens MJ, Scheper RJ, Oostrum RG, Boersma AW, van der Gaast A, Stoter G (1996) Expression of the multidrug resistance-associated protein (MRP) gene in primary non-small-cell lung cancer. Ann Oncol 7:75-81

110. Nooter K, Brutel de la Riviere G, Look MP, van Wingerden KE, Henzen-Logmans SC, Scheper RJ, Flens MJ, Klijn JG, Stoter G, Foekens JA (1997) The prognostic significance of expression of the multidrug resistance-associated protein (MRP) in primary breast cancer. Br J Cancer 76:486-493

111. Nooter K, Burger H, Stoter G (1996) Multidrug resistanceassociated protein (MRP) in haematological malignancies. Leuk Lymphoma 20:381-387

112. Nooter K, Kok T, Bosman FT, van Wingerden KE, Stoter G (1998) Expression of the multidrug resistance protein (MRP) in squamous cell carcinoma of the oesophagus and response to preoperative chemotherapy. Eur J Cancer 34:81-86

113. Norris MD, Bordow SB, Haber PS, Marshall GM, Kavallaris M, Madafiglio J, Cohn SL, Salwen H, Schmidt ML, Hipfner DR, Cole SP, Deeley RG, Haber M (1997) Evidence that the MYCN oncogene regulates MRP gene expression in neuroblastoma. Eur J Cancer 33:1911-1916

114. Norris MD, Bordow SB, Marshall GM, Haber PS, Cohn SL, Haber M (1996) Expression of the gene for multidrug-resistanceassociated protein and outcome in patients with neuroblastoma. N Engl J Med 334:231-238

115. Olson DP, Scadden DT, D'Aquila RT, De Pasquale MP (2002) The protease inhibitor ritonavir inhibits the functional activity of the multidrug resistance related-protein 1 (MRP-1). Aids 16: $1743-1747$

116. Oselin K, Mrozikiewicz PM, Pahkla R, Roots I (2003) Quantitative determination of the human MRP1 and MRP2 mRNA expression in FACS-sorted peripheral blood CD4+, CD8+, CD19+, and CD56+ cells. Eur J Haematol 71:119-123

117. Oshika Y, Nakamura M, Tokunaga T, Fukushima Y, Abe Y, Ozeki Y, Yamazaki H, Tamaoki N, Ueyama Y (1998) Multidrug resistance-associated protein and mutant p53 protein expression in non-small cell lung cancer. Mod Pathol 11: $1059-1063$

118. Oswald C, Holland IB, Schmitt L (2006) The motor domains of ABC-transporters/What can structures tell us? Naunyn Schmiedebergs Arch Pharmacol 372:385-399

119. Pajic M, Norris MD, Cohn SL, Haber M (2005) The role of the multidrug resistance-associated protein 1 gene in neuroblastoma biology and clinical outcome. Cancer Lett 228:241-246

120. Pascolo L, Fernetti C, Pirulli D, Crovella S, Amoroso A, Tiribelli C (2003) Effects of maturation on RNA transcription and protein expression of four MRP genes in human placenta and in BeWo cells. Biochem Biophys Res Commun 303:259-265

121. Payen L, Gao M, Westlake C, Theis A, Cole SP, Deeley RG (2005) Functional interactions between nucleotide binding domains and leukotriene $\mathrm{C} 4$ binding sites of multidrug resistance protein 1 (ABCC1). Mol Pharmacol 67:1944-1953

122. Payen LF, Gao M, Westlake CJ, Cole SP, Deeley RG (2003) Role of carboxylate residues adjacent to the conserved core Walker $\mathrm{B}$ motifs in the catalytic cycle of multidrug resistance protein 1 (ABCC1). J Biol Chem 278:38537-38547

123. Peng KC, Cluzeaud F, Bens M, Van Huyen JP, Wioland MA, Lacave R, Vandewalle A (1999) Tissue and cell distribution of the multidrug resistance-associated protein (MRP) in mouse intestine and kidney. J Histochem Cytochem 47:757-768

124. Poulain S, Lepelley P, Preudhomme C, Cambier N, Cornillon J, Wattel E, Cosson A, Fenaux P (2000) Expression of the multidrug resistance-associated protein in myelodysplastic syndromes. Br J Haematol 110:591-598

125. Pulaski L, Jedlitschky G, Leier I, Buchholz U, Keppler D (1996) Identification of the multidrug-resistance protein (MRP) as the glutathione-S-conjugate export pump of erythrocytes. Eur J Biochem 241:644-648

126. Qian YM, Grant CE, Westlake CJ, Zhang DW, Lander PA, Shepard RL, Dantzig AH, Cole SP, Deeley RG (2002) Photolabeling of human and murine multidrug resistance protein 1 with the high affinity inhibitor [125I]LY475776 and azidophenacyl-[35S]glutathione. J Biol Chem 277: 35225-35231

127. Qian YM, Song WC, Cui H, Cole SP, Deeley RG (2001) Glutathione stimulates sulfated estrogen transport by multidrug resistance protein 1. J Biol Chem 276:6404-6411

128. Rajagopal A, Simon SM (2003) Subcellular localization and activity of multidrug resistance proteins. Mol Biol Cell 14: 3389-3399

129. Rao VV, Dahlheimer JL, Bardgett ME, Snyder AZ, Finch RA, Sartorelli AC, Piwnica-Worms D (1999) Choroid plexus epithelial expression of MDR1 P glycoprotein and multidrug resistance-associated protein contribute to the blood-cerebrospinal-fluid drug-permeability barrier. Proc Natl Acad Sci USA 96:3900-3905

130. Ren XQ, Furukawa T, Aoki S, Nakajima T, Sumizawa $T$, Haraguchi M, Chen ZS, Kobayashi M, Akiyama S (2001) Glutathione-dependent binding of a photoaffinity analog of agosterol $\mathrm{A}$ to the $\mathrm{C}$-terminal half of human multidrug resistance protein. J Biol Chem 276:23197-23206

131. Ren XQ, Furukawa T, Haraguchi M, Sumizawa T, Aoki S, Kobayashi M, Akiyama S (2004) Function of the ABC signature sequences in the human multidrug resistance protein 1 . Mol Pharmacol 65:1536-1542

132. Renes J, de Vries EE, Hooiveld GJ, Krikken I, Jansen PL, Muller M (2000) Multidrug resistance protein MRP1 protects against the toxicity of the major lipid peroxidation product 4-hydroxynonenal. Biochem J 350(Pt 2):555-561

133. Renes J, de Vries EG, Nienhuis EF, Jansen PL, Muller M (1999) ATP- and glutathione-dependent transport of chemotherapeutic drugs by the multidrug resistance protein MRP1. Br J Pharmacol 126:681-688

134. Reyes CL, Chang G (2005) Structure of the ABC transporter MsbA in complex with ADP.vanadate and lipopolysaccharide. Science 308:1028-1031

135. Robbiani DF, Finch RA, Jager D, Muller WA, Sartorelli AC, Randolph GJ (2000) The leukotriene C(4) transporter MRP1 regulates CCL19 (MIP-3beta, ELC)-dependent mobilization of dendritic cells to lymph nodes. Cell 103:757-768

136. Ros JE, Libbrecht L, Geuken M, Jansen PL, Roskams TA (2003) High expression of MDR1, MRP1, and MRP3 in the hepatic 
progenitor cell compartment and hepatocytes in severe human liver disease. J Pathol 200:553-560

137. Rosenberg MF, Mao Q, Holzenburg A, Ford RC, Deeley RG, Cole SP (2001) The structure of the multidrug resistance protein 1 (MRP1/ABCC1). crystallization and single-particle analysis. J Biol Chem 276:16076-16082

138. Rudas M, Filipits M, Taucher S, Stranzl T, Steger GG, Jakesz R, Pirker R, Pohl G (2003) Expression of MRP1, LRP and Pgp in breast carcinoma patients treated with preoperative chemotherapy. Breast Cancer Res Treat 81:149-157

139. Sasabe H, Kato Y, Suzuki T, Itose M, Miyamoto G, Sugiyama $Y$ (2004) Differential involvement of multidrug resistance-associated protein 1 and P-glycoprotein in tissue distribution and excretion of grepafloxacin in mice. J Pharmacol Exp Ther 310:648-655

140. Scheffer GL, Pijnenborg AC, Smit EF, Muller M, Postma DS, Timens W, van der Valk P, de Vries EG, Scheper RJ (2002) Multidrug resistance related molecules in human and murine lung. J Clin Pathol 55:332-339

141. Schrenk D, Baus PR, Ermel N, Klein C, Vorderstemann B, Kauffmann HM (2001) Up-regulation of transporters of the MRP family by drugs and toxins. Toxicol Lett 120:51-57

142. Schultz MJ, Wijnholds J, Peppelenbosch MP, Vervoordeldonk MJ, Speelman P, van Deventer SJ, Borst P, van der Poll T (2001) Mice lacking the multidrug resistance protein 1 are resistant to Streptococcus pneumoniae-induced pneumonia. J Immunol 166:4059-4064

143. Seetharaman S, Barrand MA, Maskell L, Scheper RJ (1998) Multidrug resistance-related transport proteins in isolated human brain microvessels and in cells cultured from these isolates. J Neurochem 70:1151-1159

144. Shinoda C, Maruyama M, Fujishita T, Dohkan J, Oda H, Shinoda K, Yamada T, Miyabayashi K, Hayashi R, Kawagishi Y, Fujita T, Matsui S, Sugiyama E, Muraguchi A, Kobayashi M (2005) Doxorubicin induces expression of multidrug resistance-associated protein 1 in human small cell lung cancer cell lines by the c-jun $\mathrm{N}$-terminal kinase pathway. Int J Cancer 117:21-31

145. Slapak CA, Mizunuma N, Kufe DW (1994) Expression of the multidrug resistance associated protein and P-glycoprotein in doxorubicin-selected human myeloid leukemia cells. Blood 84:3113-3121

146. St-Pierre MV, Serrano MA, Macias RI, Dubs U, Hoechli M, Lauper U, Meier PJ, Marin JJ (2000) Expression of members of the multidrug resistance protein family in human term placenta. Am J Physiol Regul Integr Comp Physiol 279:R1495-R1503

147. St-Pierre MV, Stallmach T, Freimoser Grundschober A, Dufour JF, Serrano MA, Marin JJ, Sugiyama Y, Meier PJ (2004) Temporal expression profiles of organic anion transport proteins in placenta and fetal liver of the rat. Am J Physiol Regul Integr Comp Physiol 287:R1505-R1516

148. Stride BD, Grant CE, Loe DW, Hipfner DR, Cole SP, Deeley RG (1997) Pharmacological characterization of the murine and human orthologs of multidrug-resistance protein in transfected human embryonic kidney cells. Mol Pharmacol 52:344-353

149. Stride BD, Valdimarsson G, Gerlach JH, Wilson GM, Cole SP, Deeley RG (1996) Structure and expression of the messenger RNA encoding the murine multidrug resistance protein, an ATPbinding cassette transporter. Mol Pharmacol 49:962-971

150. Sugawara I, Yamada H, Nakamura H, Sumizawa T, Akiyama S, Masunaga A, Itoyama S (1995) Preferential expression of the multidrug-resistance-associated protein (MRP) in adenocarcinoma of the lung. Int J Cancer 64:322-325

151. Sugiyama D, Kusuhara H, Lee YJ, Sugiyama Y (2003) Involvement of multidrug resistance associated protein 1 (Mrp1) in the efflux transport of 17beta estradiol-D-17beta- glucuronide (E217betaG) across the blood-brain barrier. Pharm Res 20:1394-1400

152. Sullivan GF, Amenta PS, Villanueva JD, Alvarez CJ, Yang JM, Hait WN (1998) The expression of drug resistance gene products during the progression of human prostate cancer. Clin Cancer Res 4:1393-1403

153. Sullivan GF, Yang JM, Vassil A, Yang J, Bash-Babula J, Hait WN (2000) Regulation of expression of the multidrug resistance protein MRP1 by p53 in human prostate cancer cells. J Clin Invest 105:1261-1267

154. Szabo K, Welker E, Bakos, Muller M, Roninson I, Varadi A, Sarkadi B (1998) Drug-stimulated nucleotide trapping in the human multidrug transporter MDR1. Cooperation of the nucleotide binding domains. J Biol Chem 273:10132-10138

155. Szakacs G, Annereau JP, Lababidi S, Shankavaram U, Arciello A, Bussey KJ, Reinhold W, Guo Y, Kruh GD, Reimers M, Weinstein JN, Gottesman MM (2004) Predicting drug sensitivity and resistance: profiling $\mathrm{ABC}$ transporter genes in cancer cells. Cancer Cell 6:129-137

156. Szakacs G, Ozvegy C, Bakos E, Sarkadi B, Varadi A (2001) Role of glycine-534 and glycine-1179 of human multidrug resistance protein (MDR1) in drug-mediated control of ATP hydrolysis. Biochem J 356:71-75

157. Szentpetery Z, Kern A, Liliom K, Sarkadi B, Varadi A, Bakos E (2004) The role of the conserved glycines of ATP-binding cassette signature motifs of MRP1 in the communication between the substrate-binding site and the catalytic centers. J Biol Chem 279:41670-41678

158. Tada Y, Wada M, Migita T, Nagayama J, Hinoshita E, Mochida Y, Maehara Y, Tsuneyoshi M, Kuwano M, Naito S (2002) Increased expression of multidrug resistance-associated proteins in bladder cancer during clinical course and drug resistance to doxorubicin. Int J Cancer 98:630-635

159. Takayanagi S, Ishikawa $T$ (2003) Molecular identification and characterization of rat Abcc1 cDNA: existence of two splicing variants and species difference in drug-resistance profile. J Exp Ther Oncol 3:136-146

160. Takebayashi Y, Akiyama S, Natsugoe S, Hokita S, Niwa K, Kitazono M, Sumizawa T, Tani A, Furukawa T, Aikou T (1998) The expression of multidrug resistance protein in human gastrointestinal tract carcinomas. Cancer 82:661-666

161. Tatebe S, Sinicrope FA, Kuo MT (2002) Induction of multidrug resistance proteins MRP1 and MRP3 and gamma-glutamylcysteine synthetase gene expression by nonsteroidal anti-inflammatory drugs in human colon cancer cells. Biochem Biophys Res Commun 290:1427-1433

162. Thiebaut F, Tsuruo T, Hamada H, Gottesman MM, Pastan I, Willingham MC (1987) Cellular localization of the multidrugresistance gene product P-glycoprotein in normal human tissues. Proc Natl Acad Sci USA 84:7735-7738

163. Tribull TE, Bruner RH, Bain LJ (2003) The multidrug resistance-associated protein 1 transports methoxychlor and protects the seminiferous epithelium from injury. Toxicol Lett 142:61-70

164. van Brussel JP, Mickisch GH (2003) Multidrug resistance in prostate cancer. Onkologie 26:175-181

165. van der Kolk DM, de Vries EG, Noordhoek L, van den Berg E, van der Pol MA, Muller M, Vellenga E (2001) Activity and expression of the multidrug resistance proteins P-glycoprotein, MRP1, MRP2, MRP3 and MRP5 in de novo and relapsed acute myeloid leukemia. Leukemia 15:1544-1553

166. van der Kolk DM, de Vries EG, van Putten WJ, Verdonck LF, Ossenkoppele GJ, Verhoef GE, Vellenga E (2000) P-glycoprotein and multidrug resistance protein activities in relation to treatment outcome in acute myeloid leukemia. Clin Cancer Res 6:3205-3214 
167. Van Luyn MJ, Muller M, Renes J, Meijer C, Scheper RJ, Nienhuis EF, Mulder NH, Jansen PL, De Vries EG (1998) Transport of glutathione conjugates into secretory vesicles is mediated by the multidrug-resistance protein 1. Int J Cancer 76:55-62

168. Wang Q, Beck WT (1998) Transcriptional suppression of multidrug resistance-associated protein (MRP) gene expression by wild-type p53. Cancer Res 58:5762-5769

169. Westlake CJ, Cole SP, Deeley RG (2005) Role of the NH2terminal membrane spanning domain of multidrug resistance protein $1 / \mathrm{ABCC} 1$ in protein processing and trafficking. Mol Biol Cell 16:2483-2492

170. Westlake CJ, Qian YM, Gao M, Vasa M, Cole SP, Deeley RG (2003) Identification of the structural and functional boundaries of the multidrug resistance protein 1 cytoplasmic loop 3 . Biochemistry 42:14099-14113

171. Wijnholds J, deLange EC, Scheffer GL, van den Berg DJ, Mol CA, van der Valk M, Schinkel AH, Scheper RJ, Breimer DD, Borst P (2000) Multidrug resistance protein 1 protects the choroid plexus epithelium and contributes to the blood-cerebrospinal fluid barrier. J Clin Invest 105:279-285

172. Wijnholds J, Evers R, van Leusden MR, Mol CA, Zaman GJ, Mayer U, Beijnen JH, van der Valk M, Krimpenfort P, Borst P (1997) Increased sensitivity to anticancer drugs and decreased inflammatory response in mice lacking the multidrug resistanceassociated protein. Nat Med 3:1275-1279

173. Wijnholds J, Scheffer GL, van der Valk M, van der Valk P, Beijnen JH, Scheper RJ, Borst P (1998) Multidrug resistance protein 1 protects the oropharyngeal mucosal layer and the testicular tubules against drug-induced damage. J Exp Med 188:797-808

174. Wioland MA, Fleury-Feith J, Corlieu P, Commo F, Monceaux G, Lacau-St-Guily J, Bernaudin JF (2000) CFTR, MDR1, and MRP1 immunolocalization in normal human nasal respiratory mucosa. J Histochem Cytochem 48:1215-1222

175. Wright SR, Boag AH, Valdimarsson G, Hipfner DR, Campling BG, Cole SP, Deeley RG (1998) Immunohistochemical detection of multidrug resistance protein in human lung cancer and normal lung. Clin Cancer Res 4:2279-2289

176. Wu P, Oleschuk CJ, Mao Q, Keller BO, Deeley RG, Cole SP (2005) Analysis of human multidrug resistance protein 1 (ABCC1) by MALDI-TOF mass spectrometry: toward identification of leukotriene $\mathrm{c} 4$ binding sites. Mol Pharmacol 68: $1455-1465$

177. Yamane Y, Furuichi M, Song R, Van NT, Mulcahy RT, Ishikawa T, Kuo MT (1998) Expression of multidrug resistance protein/
GS-X pump and gamma-glutamylcysteine synthetase genes is regulated by oxidative stress. J Biol Chem 273:31075-31085

178. Yang R, Cui L, Hou YX, Riordan JR, Chang XB (2003) ATP binding to the first nucleotide binding domain of multidrug resistance-associated protein plays a regulatory role at low nucleotide concentration, whereas ATP hydrolysis at the second plays a dominant role in ATP-dependent leukotriene C4 transport. J Biol Chem 278:30764-30771

179. Yang R, McBride A, Hou YX, Goldberg A, Chang XB (2005) Nucleotide dissociation from NBD1 promotes solute transport by MRP1. Biochim Biophys Acta 1668:248-261

180. Yang Y, Chen Q, Zhang JT (2002) Structural and functional consequences of mutating cysteine residues in the amino terminus of human multidrug resistance-associated protein 1 . J Biol Chem 277:44268-44277

181. Zaman GJ, Flens MJ, van Leusden MR, de Haas M, Mulder HS, Lankelma J, Pinedo HM, Scheper RJ, Baas F, Broxterman HJ et al (1994) The human multidrug resistance-associated protein MRP is a plasma membrane drug-efflux pump. Proc Natl Acad Sci USA 91:8822-8826

182. Zhang DW, Gu HM, Situ D, Haimeur A, Cole SP, Deeley RG (2003) Functional importance of polar and charged amino acid residues in transmembrane helix 14 of multidrug resistance protein 1 (MRP1/ABCC1): identification of an aspartate residue critical for conversion from a high to low affinity substrate binding state. J Biol Chem 278:46052-46063

183. Zhang Y, Schuetz JD, Elmquist WF, Miller DW (2004) Plasma membrane localization of multidrug resistance-associated protein homologs in brain capillary endothelial cells. J Pharmacol Exp Ther 311:449-455

184. Zhao Q, Chang XB (2004) Mutation of the aromatic amino acid interacting with adenine moiety of ATP to a polar residue alters the properties of multidrug resistance protein 1. J Biol Chem 279:48505-48512

185. Zhou DC, Ramond S, Viguie F, Faussat AM, Zittoun R, Marie JP (1996) Sequential emergence of MRP- and MDR1-gene overexpression as well as MDR1-gene translocation in homoharringtonine-selected K562 human leukemia cell lines. Int J Cancer 65:365-371

186. Zhu Q, Center MS (1994) Cloning and sequence analysis of the promoter region of the MRP gene of HL60 cells isolated for resistance to adriamycin. Cancer Res 54:4488-4492

187. Zhu Q, Center MS (1996) Evidence that SP1 modulates transcriptional activity of the multidrug resistance-associated protein gene. DNA Cell Biol 15:105-111 